Research papers

\title{
Coupled physical, chemical, and microbiological measurements suggest a connection between internal waves and surf zone water quality in the Southern California Bight
}

\author{
Simon H.C. Wong ${ }^{\mathrm{a}}$, Alyson E. Santoro ${ }^{\mathrm{b}}$, Nicholas J. Nidzieko ${ }^{\mathrm{b}}$, James L. Hench ${ }^{\mathrm{c}}$, Alexandria B. Boehm ${ }^{\mathrm{a}, *}$ \\ a Department of Civil and Environmental Engineering, Environmental and Water Studies, Stanford University, Stanford, CA 94305, USA \\ ${ }^{\mathrm{b}}$ Horn Point Laboratory, University of Maryland Center for Environmental Science, Cambridge, MD 21613, USA \\ ${ }^{\mathrm{c}}$ Nicholas School of the Environment Marine Laboratory, Duke University, Beaufort, NC 28516, USA
}

\section{A R T I C L E I N F O}

\section{Article history:}

Received 24 June 2011

Received in revised form

8 November 2011

Accepted 7 December 2011

Available online 17 December 2011

\section{Keywords:}

Internal waves

Cross-shelf transport

Beach water quality

Fecal indicator bacteria

Nutrients

Southern California Bight

\begin{abstract}
A B S T R A C T
Internal waves have been implicated in the cross-shore transport of scalars such as larvae, nutrients, and pollutants at locations around the world. The present study combines physical measurements with a comprehensive set of surf zone water quality measurements to evaluate the possible impact of crossshore internal wave transport on surf zone water quality during two study periods. An array of oceanographic moorings was deployed in the summer of 2005 and 2006 at 10-20 m depth offshore of the beach to observe internal waves. Concurrently, surf zone water quality was assessed twice daily at night at an adjacent station (Huntington State Beach) by measuring concentration of phosphate, dissolved inorganic nitrogen (DIN), silicate, chlorophyll a, fecal indicator bacteria (FIB), and the humanspecific fecal DNA marker in Bacteroidales. The baroclinic component accounted for about $30 \%$ of the total variance in water column velocity, indicating the importance of density-driven flow during the summer when the water column was stratified. Arrival of cold subthermocline water in the very nearshore (within $1 \mathrm{~km}$ of the surf zone) was characterized by strong baroclinic onshore flow near the bottom of the water column. The near bottom, baroclinic, cross-shore current was significantly lagcorrelated with the near bottom temperature data along a cross-shore transect towards shore, demonstrating shoreward transport of cold subthermocline water. Wavelet analysis of temperature data showed that non-stationary temperature fluctuations were correlated with buoyancy frequency and the near bottom cross-shore baroclinic current. During periods of large temperature fluctuations, the majority of the variance was within the semi-diurnal band; however, the diurnal and high frequency bands also contained a substantial fraction of total variance. The bottom cross-shore baroclinic current was proposed as a proxy for shoreward transport potential by internal waves and was positively correlated with phosphate concentration in both years, silicate in 2005, and fecal indicator bacteria measurements in 2006. The results suggest internal waves are an important transport mechanism of nutrient-rich subthermocline water to the very nearshore in the Southern California Bight, and may facilitate the transport of FIB into the surf zone or enhance persistence of land-derived FIB.
\end{abstract}

(c) 2011 Elsevier Ltd. All rights reserved.

\section{Introduction}

Pollution of the surf zone by fecal indicator bacteria (FIB) can cause beach advisories and closures (U.S. Environmental Protection Agency, 1986), and the presence of dense, sometimes harmful, algal blooms can drive away beach visitors and decrease ocean aesthetics. The effects of land-based processes on coastal water quality, such as terrestrial runoff (Ahn et al., 2005; Reifel et al., 2009) and

\footnotetext{
* Corresponding author.

E-mail address: aboehm@stanford.edu (A.B. Boehm).
}

groundwater discharge (Valiela et al., 1990; Lee and Kim, 2007; de Sieyes et al., 2011) have been well documented. The present work aims to understand how oceanographic processes on the continental shelf affect surf zone water quality. In particular, we investigate whether the shoreward propagation of subthermocline water by internal waves affects surf zone water quality at a beach in Southern California.

Internal waves are produced by various mechanisms including traveling pressure fields, variable wind stress, and interactions between the barotropic tide and bottom topography (Garrett and Munk, 1979) and can propagate in any stably stratified body of water (Turner, 1973). The interaction of propagating internal 
waves with the continental slope can lead to wave breaking (Venayagamoorthy and Fringer, 2007), which can cause substantial net advection of mass and drive shoreward transport of nutrients and passive scalars (Shanks, 1983; Pineda, 1991; Leichter et al., 1996). The breaking of internal waves in shallow waters also induces vigorous vertical mixing of water column (Munk and Wunsch, 1998) and can bring the cold water and any subsurface materials to the surface (Pineda, 1994).

Internal waves on San Pedro Shelf, California, USA have been investigated in several field studies. A wastewater outfall is located $8.2 \mathrm{~km}$ off Huntington Beach (Fig. 1), and there is a general interest in whether transport of this effluent on-shore is possible. In addition, the subthermocline waters in this region are enriched in phosphate and nitrogen and can be a potential source of nutrients to the nearshore waters via internal wave transport. Internal waves have been shown to transport cold, subthermocline water to approximately $2.2 \mathrm{~km}$ from the shoreline (Boehm et al., 2002b). Shoaling internal waves, and the formation and shoreward propagation of bottom-trapped cold water (internal bolus) during stratified periods have been directly observed by Noble et al. (2009) and Nam and Send (2011) using an extensive set of physical measurements over the whole shelf. The transport by internal waves in this region is variable in strength (Noble et al., 2009; Lucas et al., 2011b; Nam and Send, 2011). Noble et al. (2009) showed that the shoreward transport by internal waves was more effective during periods of strong stratification and subtidal equatorward alongshore flow. Although these studies have enhanced the understanding of internal waves in crossshore transport, the physical measurements alone could not verify the connection of the physical mechanism to the crossshore transport of suspended or dissolved materials.

To date, few studies have attempted to directly relate variable internal wave activity with water quality measurements in the surf zone over an extended period in this region. One indirect comparison by Lucas et al. (2011b) estimated the monthly averaged horizontal nitrate flux driven by the internal tide based on offshore nutrient measurements, and found the estimated value to be sufficient to sustain the persistently elevated phytoplankton biomass over the inner shelf. For one episode in October 2006, Omand et al. (2011) documented the shoreward

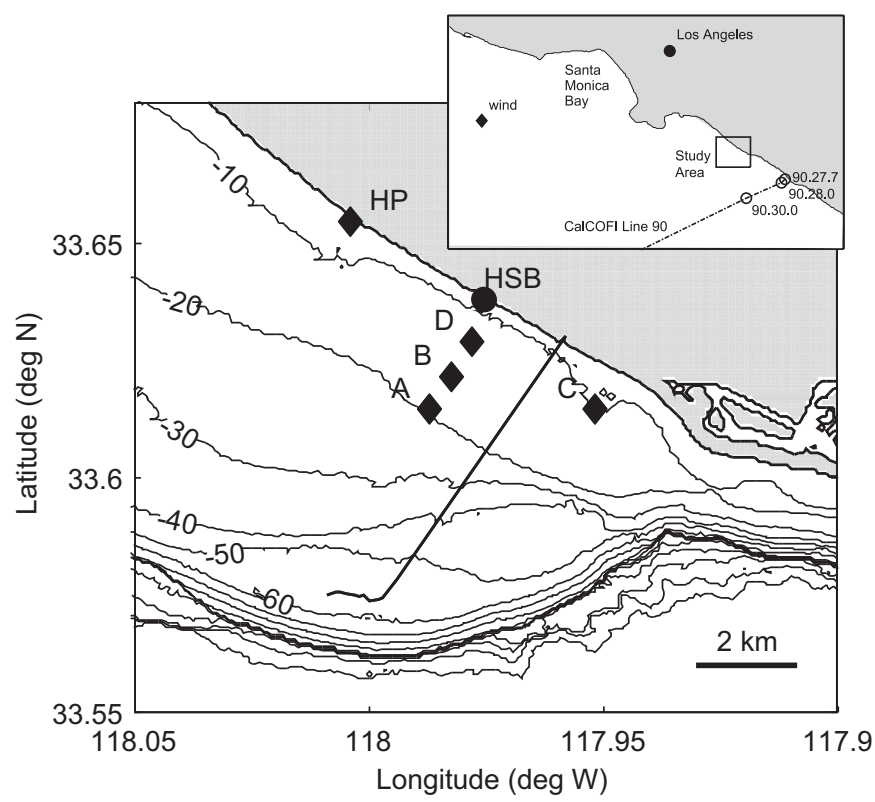

Fig. 1. Locations of oceanographic moorings (A, B, C, D, HP) and the surf zone sampling station at Huntington State Beach (HSB). The solid black line extending from the coastline is the outfall of Orange County Sanitation District. propagation of a chlorophyll a patch with internal waves and its surfacing just outside surf zone at Huntington Beach due to internal wave breaking. Rosenfeld et al. (2006) used low nearshore temperatures as a proxy for the presence of internal waves and compared it with historical water quality monitoring data at daily or lower frequency intervals at Huntington Beach. They found no connection between fecal pollution in the surf zone and internal tides from their data set in June-October 2001.

The present study combines physical measurements with a comprehensive set of surf zone water quality measurements to evaluate the possible impact of cross-shore internal wave transport on surf zone water quality. We contrast observations in the nearshore and surf zone of Huntington Beach from two different study periods: the summers 2005 and 2006. Fecal pollution was worse in the surf zone in 2006 than in 2005 (Santoro and Boehm, 2007), and conditions in 2005 supported large phytoplankton blooms in the Southern California Bight (SCB), as compared to 2006 (Santoro et al., 2010). We provide evidence consistent with previous studies that internal waves were present and episodic in strength at the field site. Further, we apply wavelet analysis to examine temporal changes in internal waves. Finally, we construct a proxy for the cross-shore transport potential by internal waves based on physical measurements and correlate this to twice-daily, night-time surf zone measurements of fecal indicator bacteria, nutrients, and chlorophyll a to investigate whether internal waves affect surf zone water quality.

\section{Data sources}

Moored instrument arrays were deployed in June-September of 2005 and 2006 to measure temperature and velocities offshore of Huntington Beach. In summer 2005, the array included five stations spanning a cross-shore transect between 10 and $20 \mathrm{~m}$ depth and an alongshore transect at $10 \mathrm{~m}$ depth (Fig. 1). At all locations, Seabird Electronics SBE-39 thermistors were installed near the bottom, and at stations A and B, additional thermistors were deployed at five and two depths, respectively (Table 1). In summer 2006, thermistors were deployed at Huntington Pier (HP) and station A only. All thermistors are referred to by their deployed location and depth. For example, A0 refers to the thermistor near bottom at station $A$, and B5 refers to the thermistor at $5 \mathrm{~m}$ above bottom (mab) at station B. A bottommounted RD Instruments Workhorse Sentinel $600 \mathrm{kHz}$ Acoustic Doppler Current Profiler (ADCP) was deployed at A during both summers. The ADCP measured velocities from $2.2 \mathrm{~m}$ to $20.2 \mathrm{mab}$ and recorded a 30-ping ensemble every $30 \mathrm{~s}$ at $1 \mathrm{~m}$ range resolution. The periods of deployment and configuration of instruments are detailed in Table 1 . The velocity data were rotated such that positive alongshore velocity $v$ is $55^{\circ}$ counterclockwise from true north as parallel to isobaths and positive cross-shore velocity $u$ is directed towards the shore.

Surf zone water quality data were collected twice daily in August 2005 and July 2006 at Huntington State Beach (HSB) in coastal Orange County, California, USA $\left(33^{\circ} 38^{\prime} \mathrm{N}, 117^{\circ} 58^{\prime} \mathrm{N}\right.$, Fig. 1$)$. On each day, waist-depth water samples were collected at high and low tide at night to avoid interfering effects of sunlight (Boehm et al., 2002a). The available water quality parameters included fecal indicator bacteria (FIB), nutrients, chlorophyll a (chl a), the human-specific marker in Bacteroidales (HF marker). FIB included total coliform (TC), E. coli (EC), and enterococci (ENT). Nutrients included nitrate, nitrite, ammonium, phosphate, and silicate. Dissolved inorganic nitrogen (DIN) was calculated as the molar sum of nitrate, nitrite, and ammonium. The detailed methods of collection and the data sets were described by Santoro and Boehm (2007) (see Table 1, Fig. 2 therein) and Santoro et al. (2010) (see Tables 2 and 3, Fig. 4 therein). 
Table 1

Mooring locations, instrumentation, and sampling schemes.

\begin{tabular}{|c|c|c|c|c|c|c|}
\hline \multirow[t]{2}{*}{ Mooring } & \multicolumn{2}{|l|}{ Location } & \multirow{2}{*}{$\begin{array}{l}\text { Water } \\
\text { depth (m) }\end{array}$} & \multirow{2}{*}{$\begin{array}{l}\text { Deployment } \\
\text { depth (mab) }\end{array}$} & \multirow[t]{2}{*}{$\Delta \mathrm{t}$} & \multirow[t]{2}{*}{ Period } \\
\hline & Latitude & Longitude & & & & \\
\hline \multicolumn{7}{|c|}{ RDI ADCP $600 \mathrm{kHz}$} \\
\hline A & $33^{\circ} 36.892^{\prime} \mathrm{N}$ & $117^{\circ} 59.223^{\prime} \mathrm{W}$ & 20 & $1 \mathrm{~m}$ bins & $30 \mathrm{~s}$ & 6 Jun-12 Sep 2005 and 15 Jun-29 Sep 2006 \\
\hline \multicolumn{7}{|c|}{ Seabird SBE39 temperature sensors } \\
\hline A & $33^{\circ} 36.892^{\prime} \mathrm{N}$ & $117^{\circ} 59.223^{\prime} \mathrm{W}$ & 20 & $0,5,7,10,15$ & $1 \mathrm{~min}$ & 6 Jun-7 Sep 2005 and 24 Mar-27 Sep 2006 \\
\hline $\mathrm{B}$ & $33^{\circ} 37.300^{\prime} \mathrm{N}$ & $117^{\circ} 58.950^{\prime} \mathrm{W}$ & 15 & 0,5 & $1 \mathrm{~min}$ & 6 Jun-7 Sep 2005 \\
\hline $\mathrm{C}$ & $33^{\circ} 36.897^{\prime} \mathrm{N}$ & $117^{\circ} 57.103^{\prime} \mathrm{W}$ & 10 & 0 & $1 \mathrm{~min}$ & 6 Jun-7 Sep 2005 \\
\hline $\mathrm{D}$ & $33^{\circ} 37.750^{\prime} \mathrm{N}$ & $117^{\circ} 58.679^{\prime} \mathrm{W}$ & 10 & 0 & $1 \mathrm{~min}$ & 6 Jun-7 Sep 2005 \\
\hline HP & $33^{\circ} 39.286^{\prime} \mathrm{N}$ & $118^{\circ} 0.232^{\prime} \mathrm{W}$ & 10 & 0 & $1 \mathrm{~min}$ & 7 Jun 2005-26 Jan 2007 \\
\hline
\end{tabular}

a

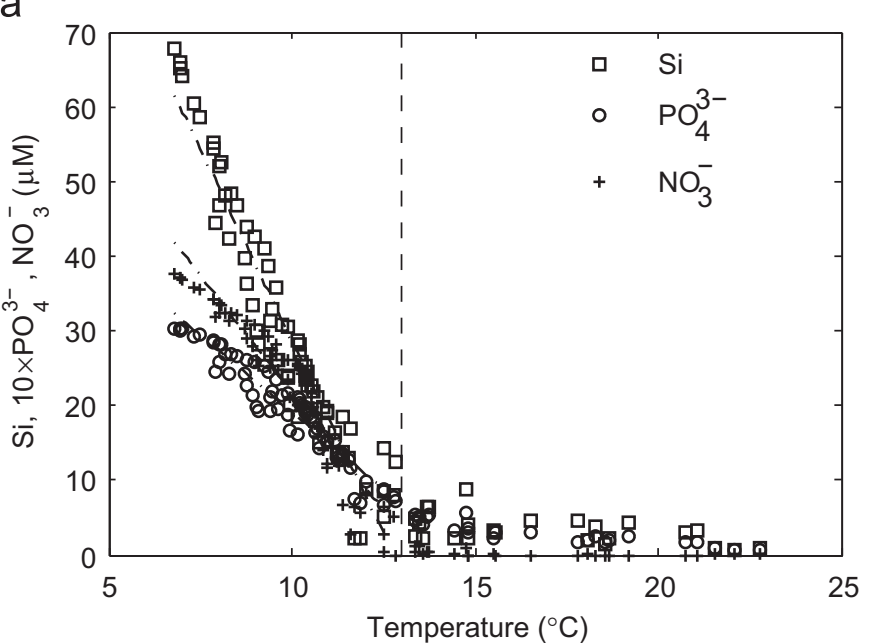

b

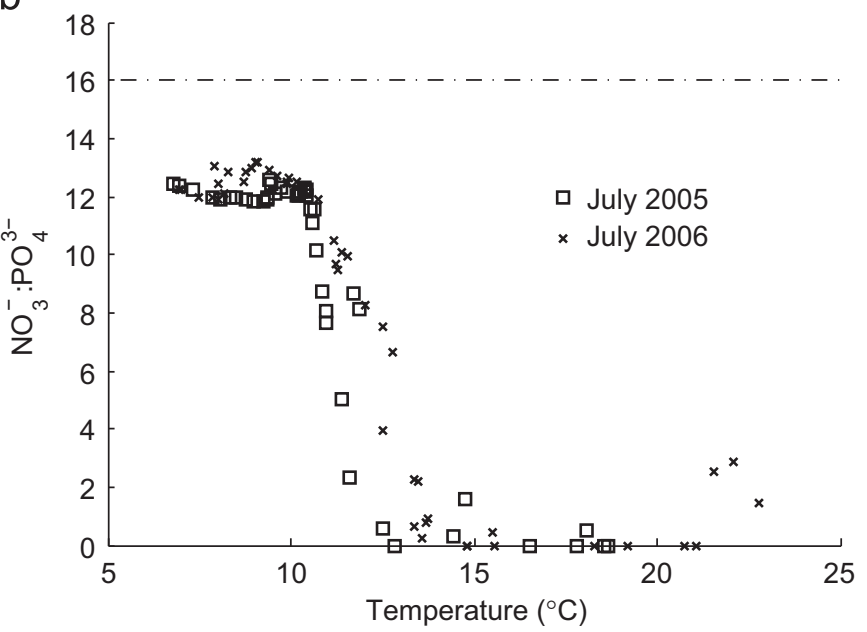

Fig. 2. (a) Relationship between water temperature $(T)$ and silicate ( $\mathrm{Si}$ ), phosphate $\left(\mathrm{PO}_{4}^{3-}\right)$, and nitrate $\left(\mathrm{NO}_{3}^{-}\right)$in the offshore waters of Huntington Beach at depth 30-700 $\mathrm{m}$ from the CalCOFI data set. Note that the concentration of phosphate was multiplied by 10 for plotting. Regression lines were drawn over each of the nutrient data for $T<13^{\circ} \mathrm{C}$; (b) scatterplot of nitrate:phosphate ratio and water temperature. The reference line is the Redfield ratio of $\mathrm{N}: \mathrm{P}=16: 1$.

Offshore silicate, phosphate, nitrate, and chlorophyll a data were obtained from quarterly monitoring cruises of the California Cooperative Oceanic Fisheries Investigations (CalCOFI) program (http://www.calcofi.org). The data collected in July 2005 and July
Table 2

Concentration of nutrients and fecal indicator bacteria (FIB) in subthermocline water and in the surf zone. The concentration of silicate, phosphate, and nitrate in subthermocline was estimated at $10^{\circ} \mathrm{C}$ waters. The concentrations of ammonium and FIB were estimated from the daily effluent data of OCSD in June-September 2005 and 2006 and an initial dilution factor of 180. The FIB concentrations in Most Probable Number (MPN)/100 mL were reported as arithmetic mean \pm standard deviation (minimum-maximum). The arithmetic mean concentrations in the surf zone in August 2005 and July 2006 were reported separately. Fecal coliform and E.coli were reported for concentrations in subthermocline waters and surf zone waters, respectively.

\begin{tabular}{lll}
\hline Nutrient $(\mu \mathrm{M})$ & Subthermocline & Surf zone $(2005,2006)$ \\
\hline Silicate & 28.7 & $4.83,5.10$ \\
Phosphate & 1.91 & $0.32,0.24$ \\
Nitrate & 21.7 & $0.23,0.24$ \\
Ammonium & 10 & $0.54,0.90$ \\
FIB (MPN/100 mL) & Near outfall & Surf zone $(2005,2006)$ \\
Total coliform & $600 \pm 1000(10-9000)$ & 2000,2000 \\
Fecal coliform/E.coli & $100 \pm 600(0-5000)$ & 300,1000 \\
Enterococci & $10 \pm 30(0-100)$ & 40,100 \\
\hline
\end{tabular}

2006 from the three most shoreward stations along Line 90 from Dana Point (station 90.30.0, 90.28.0, and 90.27.7; Fig. 1) were used to infer subthermocline water quality in the region during summer. The daily concentrations of ammonium and fecal indicator bacteria (total coliform (TC), fecal coliform (FC), and enterococci (ENT)) of the effluent of the Orange County Sanitation District (OCSD) wastewater outfall in 2005 and 2006 were supplied by OCSD. The data during May-September were used to estimate their concentrations in the marine waters near the outfall in summer.

The 6-hourly Ekman upwelling potential for the region $\left(33^{\circ} \mathrm{N}\right.$, $119^{\circ} \mathrm{W}$ ) was provided by the Pacific Fisheries Environmental Laboratory (http://www.pfeg.noaa.gov/products/PFEL/modeled/ indices/upwelling). Regional wind data were obtained from the National Data Buoy Center (NDBC) buoy \#46025 $\left(33.749^{\circ} \mathrm{N}\right.$ $119.053^{\circ} \mathrm{W} ; 100 \mathrm{~km}$ from A; Fig. 1) (http://www.ndbc.noaa.gov/ station_page.php?station=46025). It is the closest location of offshore wind data available and has been used in previous studies at Huntington Beach (e.g., Boehm et al., 2004a).

\section{Data analyses}

\subsection{Temperature data}

The vertical profile of buoyancy frequency at A was calculated using the temperature data at A. Because the summer seawater 
density in this region is mainly controlled by temperature (Jones et al., 2002), a constant salinity of 33.6 was assumed (Orange County Sanitation District, 2006). Seawater density was calculated from temperature and salinity through an equation of state (Fofonoff and Millard, 1983). The maximum buoyancy frequency at $\mathrm{A}$ was taken as the representative measure of stratification and used in the following analysis.

Continuous wavelet transforms of temperature data were used to investigate the non-stationary behavior of internal waves, resulting in the wavelet transform $W(s, t)$ at scale $s$ and time $t$ (Torrence and Compo, 1998). The Morlet wavelet was used as the mother function, with the parameter $\omega_{0}$ (as in Torrence and Compo, 1998) set to be 6 (Farge, 1992). With these parameters, the wavelet scale $s$ and the Fourier frequency are nearly identical and can be used interchangeably. To obtain a single numerical measure of wavelet power at time $t$, the wavelet power was averaged between scales $s_{1}$ to $s_{2}$

$$
\langle W\rangle(t)=\frac{\delta j \delta t}{C_{\delta}} \sum_{s=s_{1}}^{s_{2}} \frac{|W(s, t)|^{2}}{s}
$$

In this study the scale resolution $\delta j=2^{-3}$, the sampling time interval $\delta t=60 \mathrm{~s}$, and the reconstruction constant $C_{\delta}=0.776$. Unless specified, all scale-averaged wavelet powers were averaged between the buoyancy frequency (approximately $0.03 \mathrm{~Hz}$ ) and the inertial frequency $\left(1.28 \times 10^{-5} \mathrm{~Hz}\right)$, the permissible frequency range for unforced, freely propagating internal waves (Garrett and Munk, 1979). The inertial period at this latitude is $21.7 \mathrm{~h}$, so the power contained in the diurnal frequency is not included in calculating $\langle W\rangle(t)$. Computer programs developed by Torrence and Compo (1998) were used for the analysis.

\subsection{Velocity data}

The 30 -s velocity measurements were averaged into 15 -min bins for analysis. Due to missing data near the water surface, only the data $2-16 \mathrm{~m}$ above bottom of the $20 \mathrm{~m}$ water column were used. Complex Empirical Orthogonal Function (CEOF) Analysis was used to decompose horizontal velocity $(u+\mathrm{i} v)$ into their principal components. Being a complex vector, the mode shape, or eigenvector, of each principal component was oriented such that its bottom-most component pointed shoreward, and its crossshore component of the mode shape was found by taking its real part. The barotropic, density-independent contribution was defined as the first principal component and the baroclinic, density dependent contribution as summation of the second through fifth components (Stacey et al., 2001; Edwards and Seim, 2008).

To find the horizontal current ellipses of each principal component, the mean velocity in each principal component was subtracted, and the deviations from the mean were rotated to their principal axes by finding the eigenvectors of their covariance matrix. The major and minor axes of a current ellipse represent one standard deviation in the principal directions.

\subsection{Correlation}

All reported correlations refer to Spearman's rank correlation $\rho$. Non-parametric correlations were used because a number of the variables (water temperature, current, buoyancy frequency, Ekman upwelling index, and wavelet power) were not normal based on Lilliefors test of normality at the 5\% significance level. Unless specified, significant correlations have $p<0.05$. In calculating statistical significance of correlations, the artificial amplification of correlation due to autocorrelation was accounted for by using the effective degrees of freedom (Chelton, 1984).

\section{Results}

\subsection{Subthermocline water quality}

Concentrations of silicate, phosphate, and nitrate from the CalCOFI data increased approximately linearly with decreasing water temperature $(T)$ when $T$ is below about $13^{\circ} \mathrm{C}$ (Fig. 2; also, Hayward and Venrick, 1998). In this temperature range, a regression line was drawn between each water quality parameter and water temperature $\left(R^{2}>0.9\right)$. Near the shelf break (i.e., station 90.28 , depth $=60 \mathrm{~m}$ ), the typical water temperature below the thermocline was about $10{ }^{\circ} \mathrm{C}$. Using the regression equations, the nutrient concentrations in $10^{\circ} \mathrm{C}$ water were estimated to be: silicate $=28.7 \mu \mathrm{M}$, nitrate $=21.7 \mu \mathrm{M}$, and phosphate $=1.9 \mu \mathrm{M}$. For comparison, Table 2 shows their arithmetic mean (AM) concentration in the surf zone of HSB in August 2005 and July 2006. Nitrate concentration in subthermocline water was 100 times higher than its surf zone concentration, and the concentrations of silicate and phosphate were an order of magnitude higher than surf zone concentrations.

During the time of this study, the outfall discharged an average of $8.97 \times 10^{8} \mathrm{~L} \mathrm{day}^{-1}$ disinfected primary-treated sewage (Orange County Sanitation District, 2006), which still contained fecal indicator organisms despite disinfection. The concentrations of ammonium and fecal indicator bacteria (FIB) in the marine waters near the outfall were estimated by dividing their concentrations in the effluent of the outfall by the outfall's initial dilution factor of 1:180 (Noble et al., 2003, Chapter 1). We assumed that the EC:FC ratio was unity (Gannon and Busse, 1989) and used FC was an estimate of EC near the outfall. Although the arithmetic mean concentrations of TC, EC, ENT near the outfall were an order of magnitude smaller than their corresponding surf zone mean concentrations (Table 2), FIB concentrations varied by 2-3 orders of magnitude such that FIB concentrations near the outfall were at times greater than the surf zone concentration for TC and EC. FIB data from the surf zone can be found in Santoro and Boehm (2007) (Table 1, Fig. 2 therein).

\subsection{Temperature structure}

At station $A$, the vertical thermal structure was continuously stratified (Fig. 3), with 2005 more strongly stratified on average than 2006. The average stratification near the bottom of $B$ was similar to the near-bottom stratification at A. The maximum buoyancy frequency $(N)$ ranged from $1.6 \times 10^{-2}$ to $4.9 \times 10^{-2} \mathrm{~s}^{-1}$ (Figs. 4a, 5a). The 3-day low-passed near bottom temperature at $\mathrm{A}$ and HP $(T)$ showed several long-period cooling events in 10-20 m deep water that lasted for multiple days to weeks (Figs. 4a, 5a). These occurred, for example, during 10-24 June, 28 July-1 August 2005, and 25 June-2 July, 20-24 July 2006. Periods of warming could be observed, for example, during 6-13 July 2005, and 18-25 June, 25-31 July 2006. While there may be a number of reasons for the low-frequency variation of water temperature, such as large scale subtidal circulation (Hamilton et al., 2006) and remotely forced nearshore upwelling (Pringle and Riser, 2003; Boehm et al., 2004a), this study does not attempt to examine the observed low-frequency temperature variation and concentrates on the temperature variation and transport at frequencies higher than tidal periods.

An expanded view of temperature at A in August 2005 shows that on shorter time scales, the temperature at A was characterized by fluctuations at semi-diurnal and higher frequencies (Fig. 4e). The oscillations near bottom were smaller than those at the middle of the water column. Spectral analysis of the temperature data in summer 2005 and 2006 reveals well-defined spectral peaks at diurnal and semi-diurnal frequencies (Fig. 6). At $A$, the semi-diurnal spectral peak of near bottom temperature 


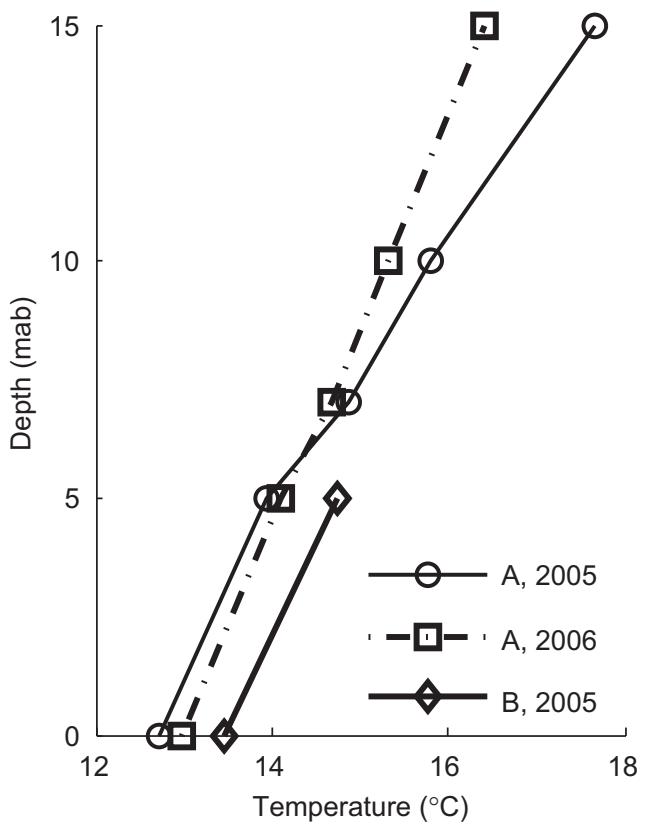

Fig. 3. Vertical structure of mean water temperature at $A$ in summer 2005 and 2006, and the near bottom mean water temperature at B in summer 2005.

(A0) was smaller than locations higher in the water column (A5, A7, A10, A15). Similar variations in spectral power with depth were observed at B. Diurnal spectral peaks were observed at A15, B, and D, and were prominent at HP. Smaller but noticeable peaks were also found at tidal harmonics of higher frequency (e.g., A7). The spectra at A and HP in the two summers were qualitatively the same.

\subsection{Wavelet spectrum of temperature data}

The wavelet power spectrum of temperature at A7 in 2005 illustrates typical results of the temporal and frequency content of the temperature data (Fig. 7a). The higher spectral peaks at A7 (Fig. 6) compared to the other depths at $A$ is consistent with the presence of mode- 1 internal waves which are more prominent in the middle of the water column than at other depths (Saggio and Imberger, 1998). In summer 2005, periods of high wavelet power, presumably high internal wave activity, lasted for 3-7 days and occurred during mid-June, mid-late July, and late August. The highest wavelet power was concentrated near the diurnal and semi-diurnal tidal frequencies. An expanded view of the wavelet spectrum in August during the period of surf zone sampling illustrates daily changes in the frequency content (Fig. 7b, c). On some days when there was high power in the semi-diurnal or diurnal frequencies, the power was high at even higher frequencies, suggesting the co-occurrence of high activity in the low and high frequency ranges or a transfer of energy from low to high frequencies (indicated by arrows in Fig. 7c). The wavelet power in summer 2006 also displayed significant temporal variation (Fig. 8). In comparison, there was generally higher internal wave activity during the surf zone sampling in July 2006 than during August 2005 (Figs. 7b, 8b).

Temporal variation in three frequency bands during summer 2005 was investigated by scale-averaging the wavelet spectrum: high frequency $\left(f>4.630 \times 10^{-5} \mathrm{~Hz}\right)$, semi-diurnal $\left(1.984 \times 10^{-5}\right.$ $\left.\mathrm{Hz}<f<2.778 \times 10^{-5} \mathrm{~Hz}\right)$, and diurnal $\left(1.263 \times 10^{-5} \mathrm{~Hz}<f<\right.$ $1.068 \times 10^{-5} \mathrm{~Hz}$ ). We calculated the percentage of the total variance in each band during "high wavelet power" events, which were defined to have the highest $10 \%$ wavelet power in the entire period. In the lower half of the water column (A0, A5, A7, B0, B5,
Table 3

Spearman's rank correlation between hourly wavelet powers in the three frequency bands in summer 2005. HF: high frequency; D2: semi-diurnal frequency; D1: diurnal frequency.

\begin{tabular}{llll}
\hline \multirow{2}{*}{ Station } & \multicolumn{2}{l}{ Pairs of frequency bands } \\
\cline { 2 - 4 } & HF and D2 & D1 and D2 & HF and D1 \\
\hline A0 & 0.69 & 0.41 & 0.44 \\
A5 & 0.50 & $0.17^{\mathrm{a}}$ & 0.25 \\
A7 & 0.41 & $0.13^{\mathrm{a}}$ & 0.23 \\
A10 & 0.25 & 0.29 & 0.32 \\
A15 & 0.66 & 0.37 & 0.41 \\
B0 & 0.67 & 0.32 & 0.41 \\
B5 & 0.53 & 0.27 & 0.30 \\
D0 & 0.67 & 0.41 & 0.45 \\
HP & 0.45 & 0.40 & $0.10^{\mathrm{a}}$ \\
\hline
\end{tabular}

${ }^{a}$ Refers to correlations not significant at $p<0.05$.

D0, HP), the semi-diurnal band contained a significant portion of the total power (33-50\%), whereas the diurnal band contained 4$22 \%$. In the upper half of the water column (A10 and A15), the diurnal band contained more power $(30-34 \%)$ than the semidiurnal band (18-19\%). The high frequency band of all stations contained 7-14\% of the total power. Analysis of summer 2006 data at $\mathrm{A}$ and HP produced consistent results.

The relationship among the hourly wavelet power in the three bands in summer 2005 was investigated (Table 3). The highest significant correlations were often found between the power in the high frequency and semi-diurnal bands $(\rho=0.25-0.69, p<0.05$ at all stations). The power in the diurnal and semi-diurnal bands was significantly correlated at all stations $(\rho=0.27-0.41, p<0.05)$ except at A5 and A7 ( $\rho=0.13-0.17)$. The high frequency and diurnal bands were significantly correlated at all stations $(\rho=0.23-0.45$, $p<0.05)$ except at HP $(\rho=0.10)$.

\subsection{Correlations between temperature fluctuations and environmental variables}

In 2005, stratification, in terms of buoyancy frequency, covaried with near surface temperature and not near bottom temperature. Buoyancy frequency was highly correlated with temperature at A15 ( $\rho=0.72, p<0.05$, both binned daily) but not with temperature at A0 $(\rho=0.05)$. The association between buoyancy frequency and wavelet power of temperatures in the three frequency bands was also examined. Buoyancy frequency was significantly and positively correlated with the wavelet power in high frequency and semi-diurnal bands at the near bottom stations, e.g., A0, A5, B0, B5, D0, HP $(\rho=0.44-0.61$, $p<0.05$ ) but was not correlated to the power in these bands at A10 an A15. Buoyancy frequency was uncorrelated with the wavelet power in the diurnal band at all stations. The near bottom temperature at $A$ was significantly lag-correlated with the depth averaged alongshore velocity at A $(\rho=0.36$, lag $=4 \mathrm{~d})$ (Fig. 4b) and inversely correlated with the Ekman upwelling index with zero lag (Fig. 4c) $(\rho=-0.37)$. Correlation of the band-passed temperature at the three bands with the onshore component of the wind speed reveals that, at all stations, the onshore wind speed was significantly and positively correlated with the diurnal band temperature $(\rho=0.30-0.43, p<0.05)$, but not the high frequency and semi-diurnal band ( $\rho=-0.04$ to 0.04 ).

By contrast, 2006 was characterized by a high correlation between buoyancy frequency and both near bottom (A0, $\rho=0.39$, $p<0.05$ ) and near surface temperature (A15, $\rho=0.81, p<0.05$ ); insignificant correlations between near bottom temperature and alongshore velocity at any lag; and insignificant correlation 
a

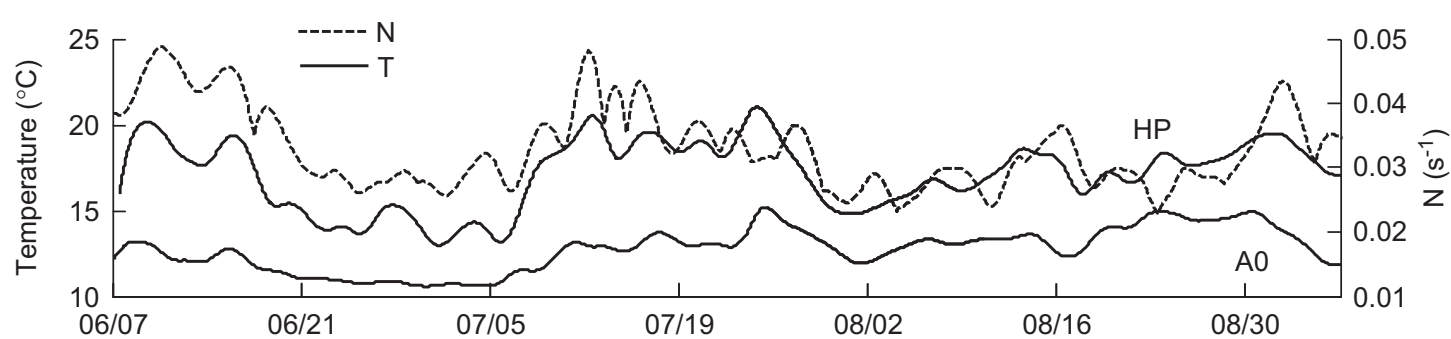

b
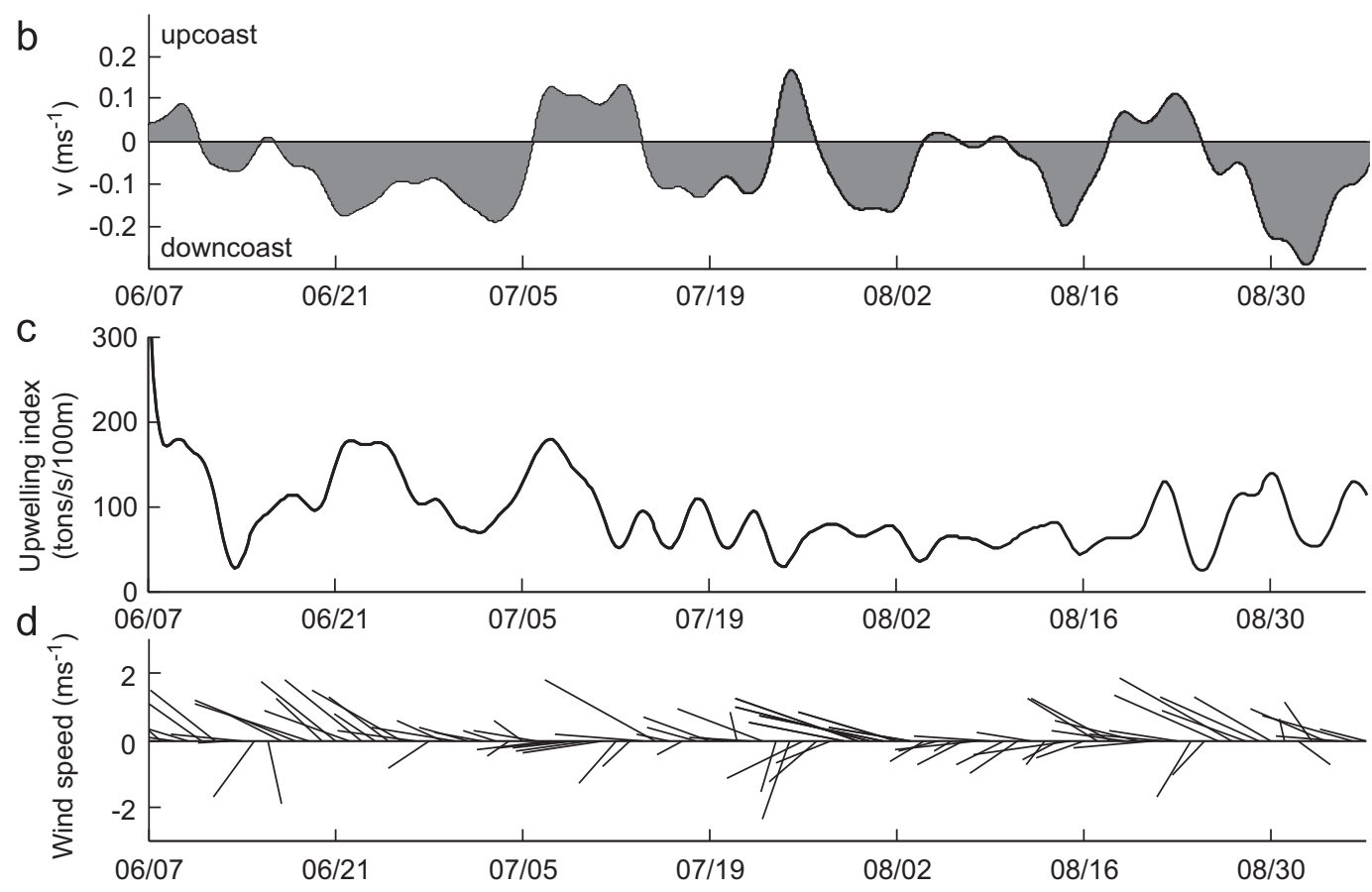

e

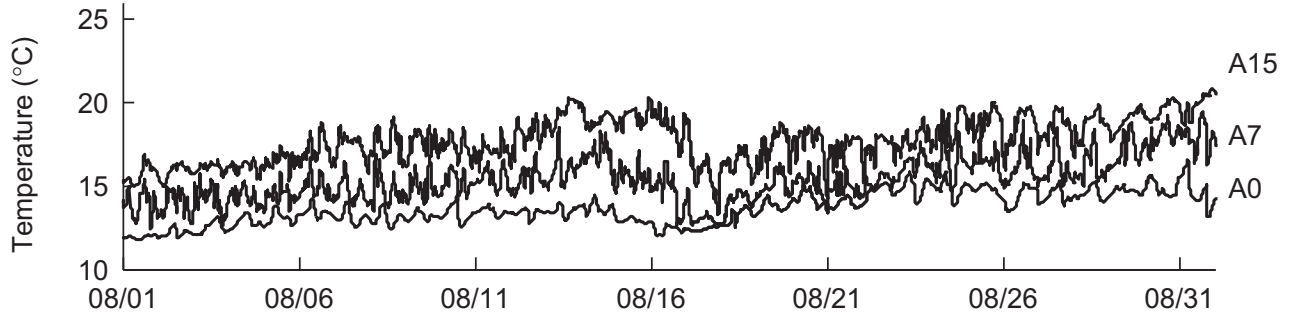

$f$

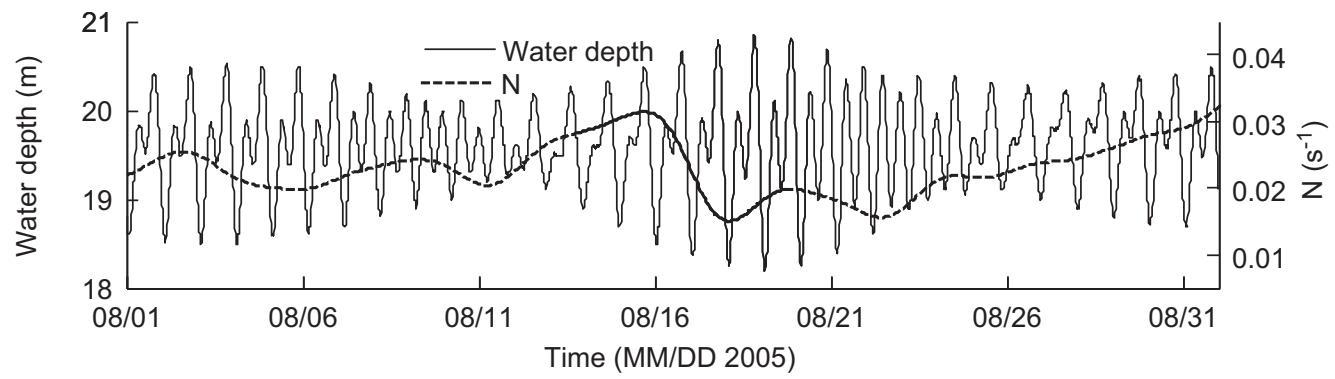

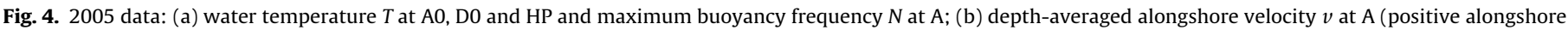

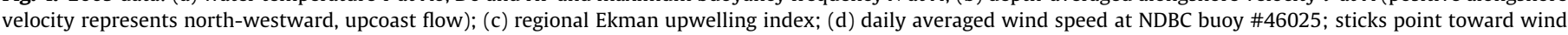

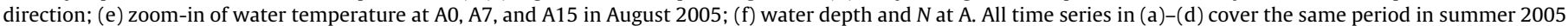

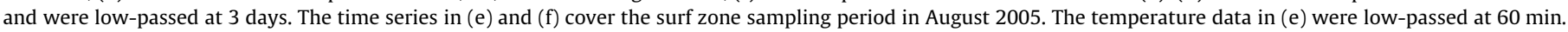

between near bottom temperature and Ekman upwelling index (Fig. 5). Buoyancy frequency was significantly correlated with the wavelet power of temperatures in the three bands at A0, A5, and A7 $(\rho=0.29-0.53, p<0.05)$ and insignificant at A15 and HP. As in 2005 , onshore wind speed was correlated with the temperature band-passed at the diurnal band ( $\rho=0.30-0.39, p<0.05)$, but not the high frequency and semi-diurnal band ( $\rho=-0.02$ to 0.04 ).

\subsection{Current structure}

To better understand the potential for cross-shelf transport, the cross-shore vertical structure and orientation of the horizontal velocity at A were examined using CEOF. The cross-shore vertical structure in the 2 years was qualitatively the same so only the results in 2005 are illustrated. In the cross-shore direction, 
a

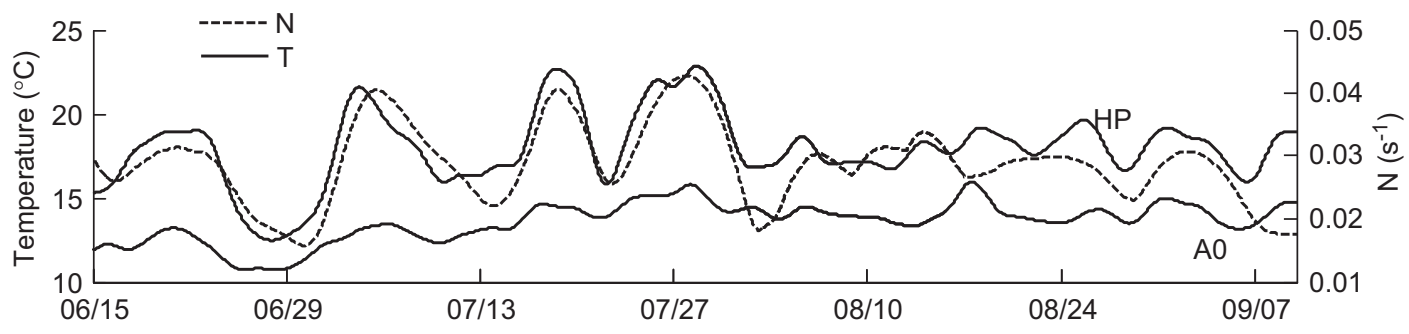

b

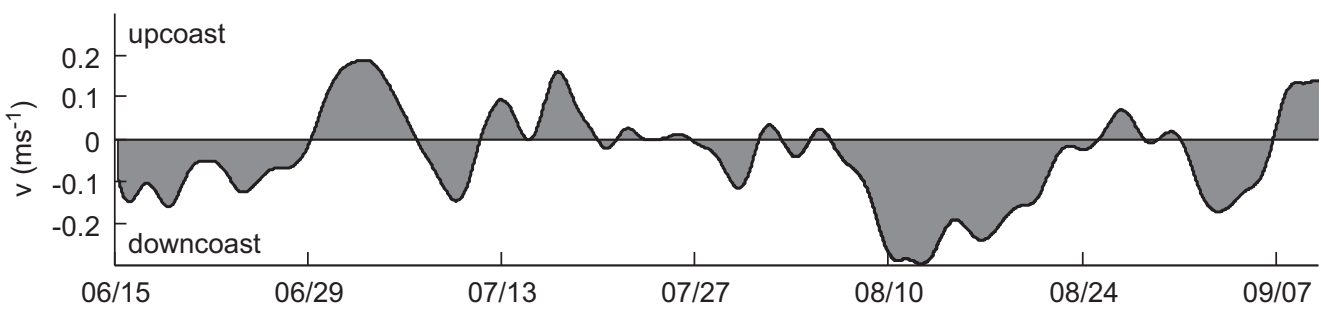

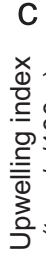

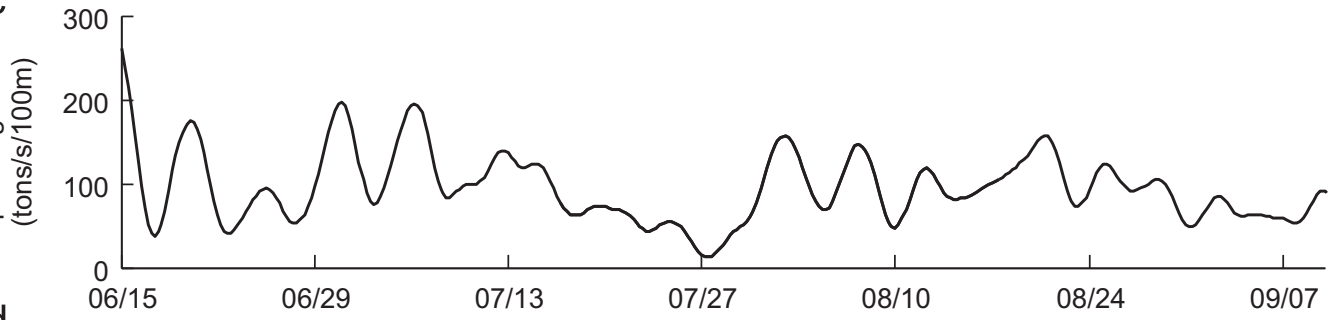

d

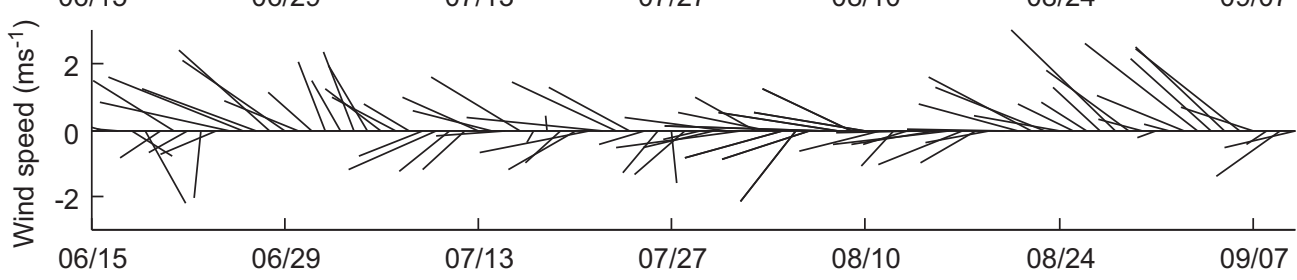

e

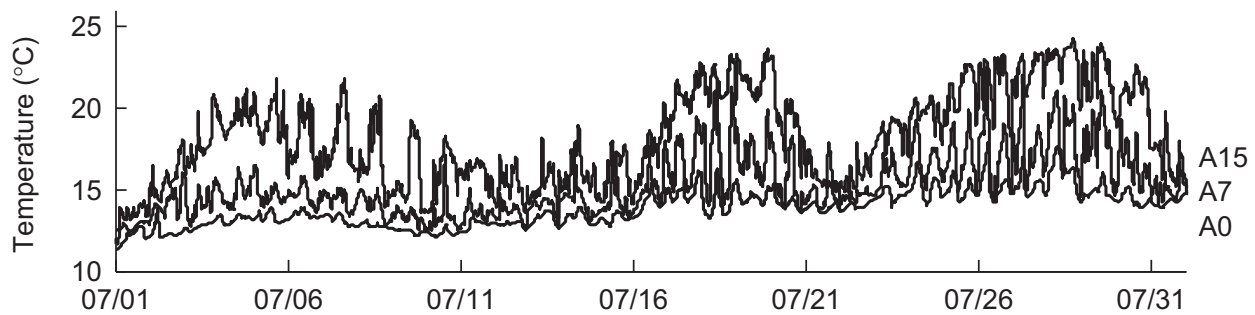

f

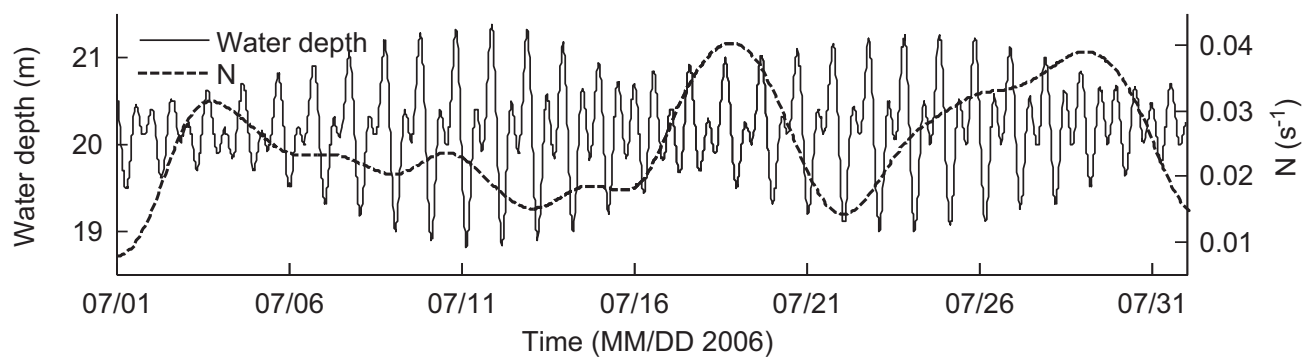

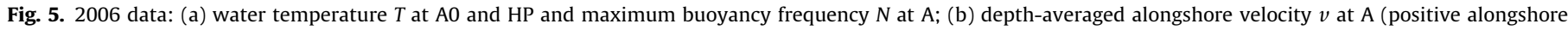

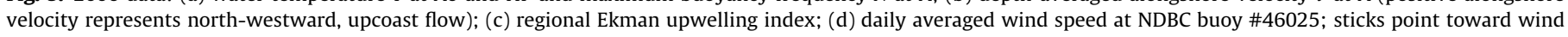

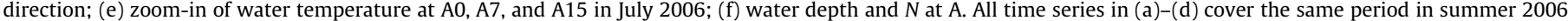

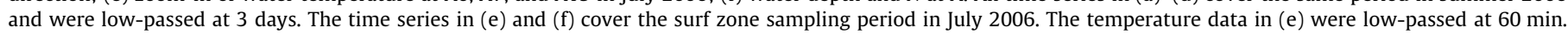

the first principal component (pc1) displays a typical logarithmic boundary layer profile with a reduction in magnitude near the bed and represents a barotropic current (Fig. 9a). The next two components show the typical vertical structure associated with internal waves: pc2 shows two-layer sheared flow and resembles the mode 1 baroclinic current; pc3 is a three-layer flow, where the middle one-third of the flow is out of phase with the surface and bottom flow.

In the horizontal direction (Fig. 9b), the major axis of pc1 averaged over summer 2005 was oriented alongshore at all depths, with a higher variability at the upper than lower water column. In comparison, pc2 and pc3 were aligned closer to the 


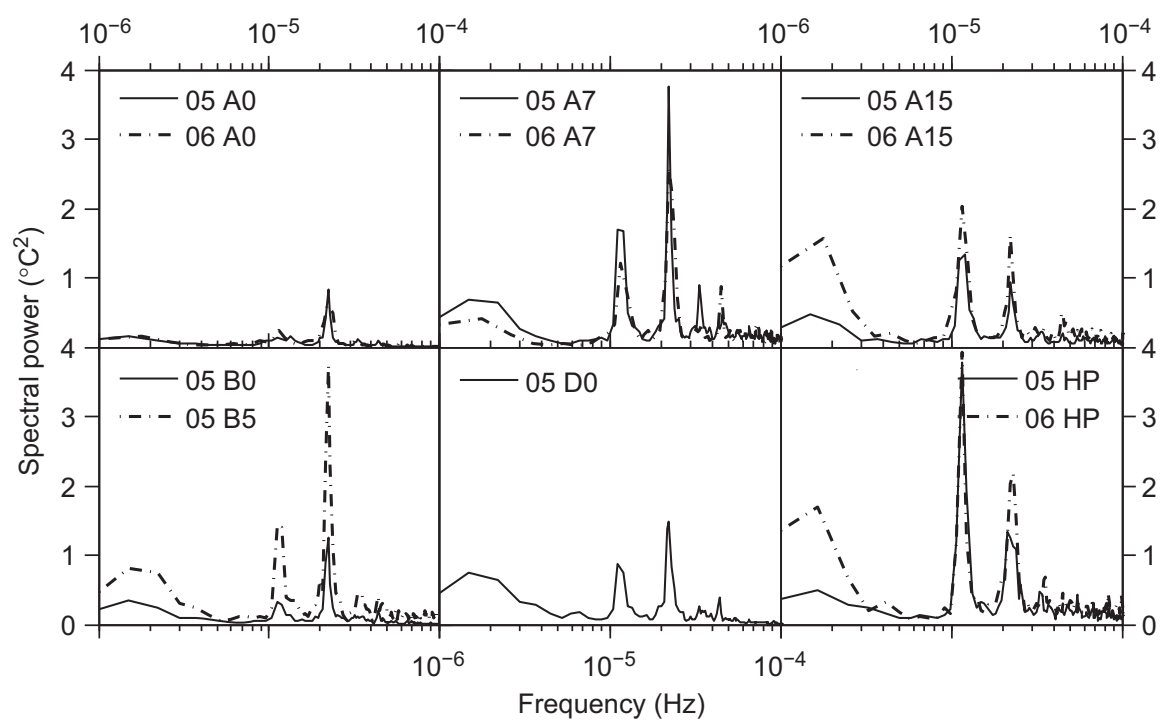

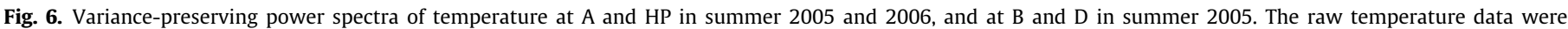

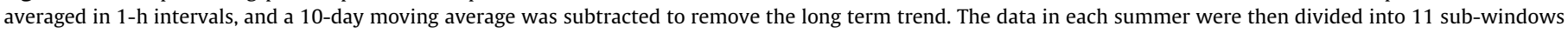
with a $50 \%$ overlap, detrended using a linear fit to each sub-window, and multiplied by a Hann window.

cross-shore direction, as suggested by the longer cross-shore extent of ellipses, and shared a similar depth-dependent orientation. Near bottom, pc2 and pc3 played a more important role than pc1 in the cross-shore direction, as suggested by their longer cross-shore length of ellipses.

In summer $2005,68.4 \%$ of the total variance in horizontal velocity is accounted for by pc1 (barotropic tides), but pc 2 and pc3 also explained a significant portion of the variance $(22.9 \%$ and $5.4 \%$, respectively). Similarly, pc1, pc2, and pc3 in summer 2006 explained $73.3 \%, 19.9 \%$, and $4.1 \%$, respectively. In both years, over $99 \%$ of the total variance could be summarized by the first five principal components. In the following, baroclinic currents refer to the velocity time series reconstructed from the summation of the second through fifth principal components.

\subsection{Relationship between currents and short period temperature fluctuations}

We examined the cross-shore component of the baroclinic current to investigate the cross-shore transport potential by internal waves. A relationship between the semi-diurnal temperature fluctuations and cross-shore baroclinic current was repeatably observed. This is exemplified by the data on 17 June 2005 when there was a clear connection between the arrival of cold water and an onshore baroclinic flow at the base of the water column (Fig. 10a, b). Between 0200 and 0600 h, cold water arrived at $\mathrm{A}$ and the cross-shore baroclinic current was highly sheared with a strong onshore bottom flow and offshore surface flow, resembling the current structure of mode- 1 internal waves. The near bottom flow was at times greater than $0.15 \mathrm{~m} \mathrm{~s}^{-1}$. At $1200 \mathrm{~h}$, the direction of the baroclinic current reversed. The bottom current flowed offshore as the denser subthermocline water moved back along the bottom, while warm water in the upper water column moved onshore.

Temperature records at A, B, D, and HP illustrate the propagation of the cold water mass cross-shore during the same period of time (Fig. 10c). HP, located off the cross-shore transect (Fig. 1), was taken to represent the temperature just outside surf zone. The temperature drop at $\mathrm{A}$ at $0300 \mathrm{~h}$ was followed by subsequent drops at $\mathrm{B}, \mathrm{D}$, and then $\mathrm{HP}$ about $1,3,6 \mathrm{~h}$ later, respectively (Fig. 10b, c). The minimum temperatures at A and B differed by about $0.5{ }^{\circ} \mathrm{C}$, consistent with the same water mass traveling from
A to $\mathrm{B}$ with some vertical mixing. The minimum temperature at $\mathrm{D}$ was $1{ }^{\circ} \mathrm{C}$ above the minimum temperature at $\mathrm{B}$, whereas temperature at $\mathrm{HP}$ dropped to a minimum of $16{ }^{\circ} \mathrm{C}$ or $4{ }^{\circ} \mathrm{C}$ above the minimum temperature at $\mathrm{B}$. The regular beach monitoring data at the surf zone of HSB also showed a decrease of temperature to $16.6{ }^{\circ} \mathrm{C}$ in the morning of June 18 from $18.2^{\circ} \mathrm{C}$ on June 16 (data not shown).

Assuming propagation perpendicular to the coastline, the phase speed of internal waves on 17 June 2005 was estimated to be $31 \mathrm{~cm} \mathrm{~s}^{-1}$ between $A$ and $B, 20 \mathrm{~cm} \mathrm{~s}^{-1}$ between $B$ and $D$, and, $15 \mathrm{~cm} \mathrm{~s}^{-1}$ between $\mathrm{D}$ and HP, based on cross-correlation analyses of temperature. The theoretical phase speed $\left(C_{p}\right)$ of a linear hydrostatic first mode internal wave is (Gill, 1982): $C_{p}=D N / \pi$, where $D$ is the water depth and $N$ is the buoyancy frequency. Thus, the observed decrease in propagation in shallower waters is consistent with theory. Using the mean and standard deviation of maximum $N$ at $\mathrm{A}$ on 17 June 2005, the theoretical linear first mode $C_{p}$ was $24 \pm 3 \mathrm{~cm} \mathrm{~s}^{-1}$ between $A$ and B. Similarly, using $N$ at B, $C_{p}$ was $8 \pm 5 \mathrm{~cm} \mathrm{~s}^{-1}$ between B and D. The higher observed phase speeds than the theoretical linear wave speeds might suggest that the observed internal waves became nonlinear at the shallow depth (Helfrich and Melville, 2006). In addition, at B (15 $\mathrm{m}$ depth), $N$ calculated from the temperature at B0 and B5 (the only available data), may underestimate the true maximum $N$ at the water column, resulting in a lower estimate of $C_{p}$.

Although we did not have data offshore of $\mathrm{A}$, a first order estimate of the travel time $t$ from the shelf break $\left(D_{s b} \approx 60 \mathrm{~m}\right)$ where the outfall discharge is located to $\mathrm{A}\left(D_{A}=20 \mathrm{~m}\right)$ can be made by assuming constant slope $S=(60 \mathrm{~m}-20 \mathrm{~m}) / 5400 \mathrm{~m}=7.4$ $\times 10^{-3}$ and constant $N$ in between

$t=\int_{s b}^{A} \frac{d x}{C_{p}(x)}=\int_{s b}^{A} \frac{\pi}{N D} \frac{d D}{S}=\frac{\pi}{S N} \ln \frac{D_{s b}}{D_{A}}$

Here, it has been assumed that the phase speed is the same as the propagation speed of water mass. When an internal bolus is formed, as observed by Nam and Send (2011), the propagation speed of the bolus was computed to be around 0.7-1.2 of the phase speed (Venayagamoorthy and Fringer, 2007). Using estimates of $N=0.01-0.04 \mathrm{~s}^{-1}$ from summer 2005, Eq. (2) gives a travel time ranging from 3 to $13 \mathrm{~h}$. 

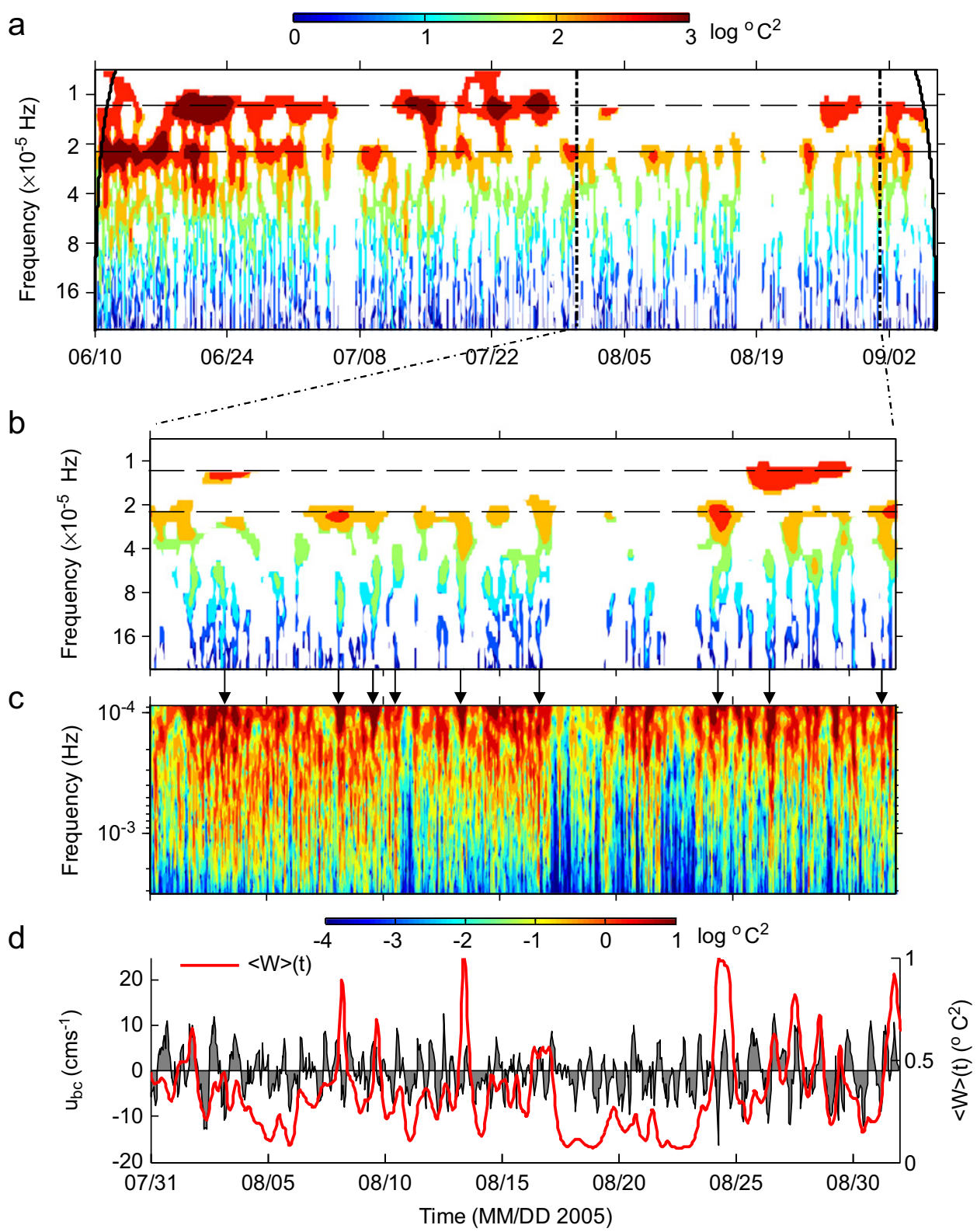

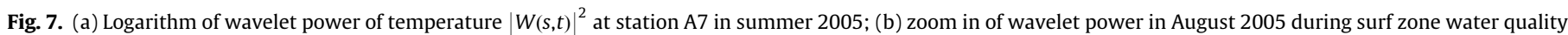

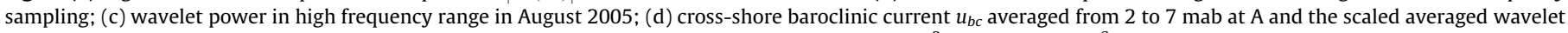

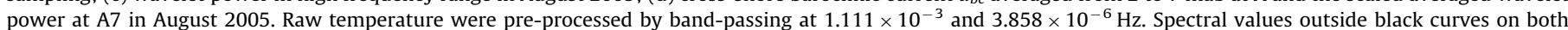

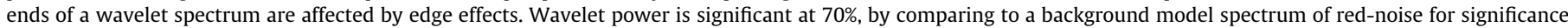
testing (Torrence and Compo, 1998). Dashed lines in (a) represent semi-diurnal $\left(2.24 \times 10^{-5}\right)$ and diurnal $\left(1.16 \times 10^{-5}\right)$ tidal periods.

\subsection{Proxy for shoreward internal wave propagation}

The cross-shore near bottom baroclinic current $\left(u_{b c}\right)$ at $\mathrm{A}$ (averaged over 2-7 mab) appears to be a good proxy for the cross-shore transport potential by internal waves at the field site (Figs. 7d, 8d). A spectral analysis of $u_{b c}$ indicates that it has dominant spectral peaks at the semi-diurnal frequency and lower peaks at diurnal and other higher tidal harmonics with minimal energy at lower frequencies (Fig. 11). Since internal waves do not necessarily propagate cross-shore, the proxy captures the crossshore transport potential by considering only the cross-shore component of the baroclinic current. It does not assume motions in particular frequencies and is based on the summation of the second to fifth principal components of currents, which include a majority of the variance of the baroclinic motions.
In 2005, this proxy showed a negative, significant correlation with the 40-h high-passed temperature at B, D, and HP at different time lags. The highest correlations between the proxy and temperature at B, D, and HP occurred at lags of $3 \mathrm{~h}, 5 \mathrm{~h}$, and $7 \mathrm{~h}$, respectively. The correlation strength decreased with increased separation distance from A: $\rho=-0.565$ at $\mathrm{B}, \rho=-0.463$ at $\mathrm{D}, \rho=-0.363$ at HP. In 2006 , the proxy was also negatively lag correlated with temperature at HP ( $\rho=-0.353$; lag $=7 \mathrm{~h})$, implying a link between onshore flow near bottom and cooling.

The association between $u_{b c}$ and the wavelet power of temperature was investigated by correlating their daily maximum values instead of their original time series. The later comparison is not logical because, while $u_{b c}$ can fluctuate over positive and negative extreme values, the use of Morlet wavelet combines both positive and negative peaks into a single broad peak, 


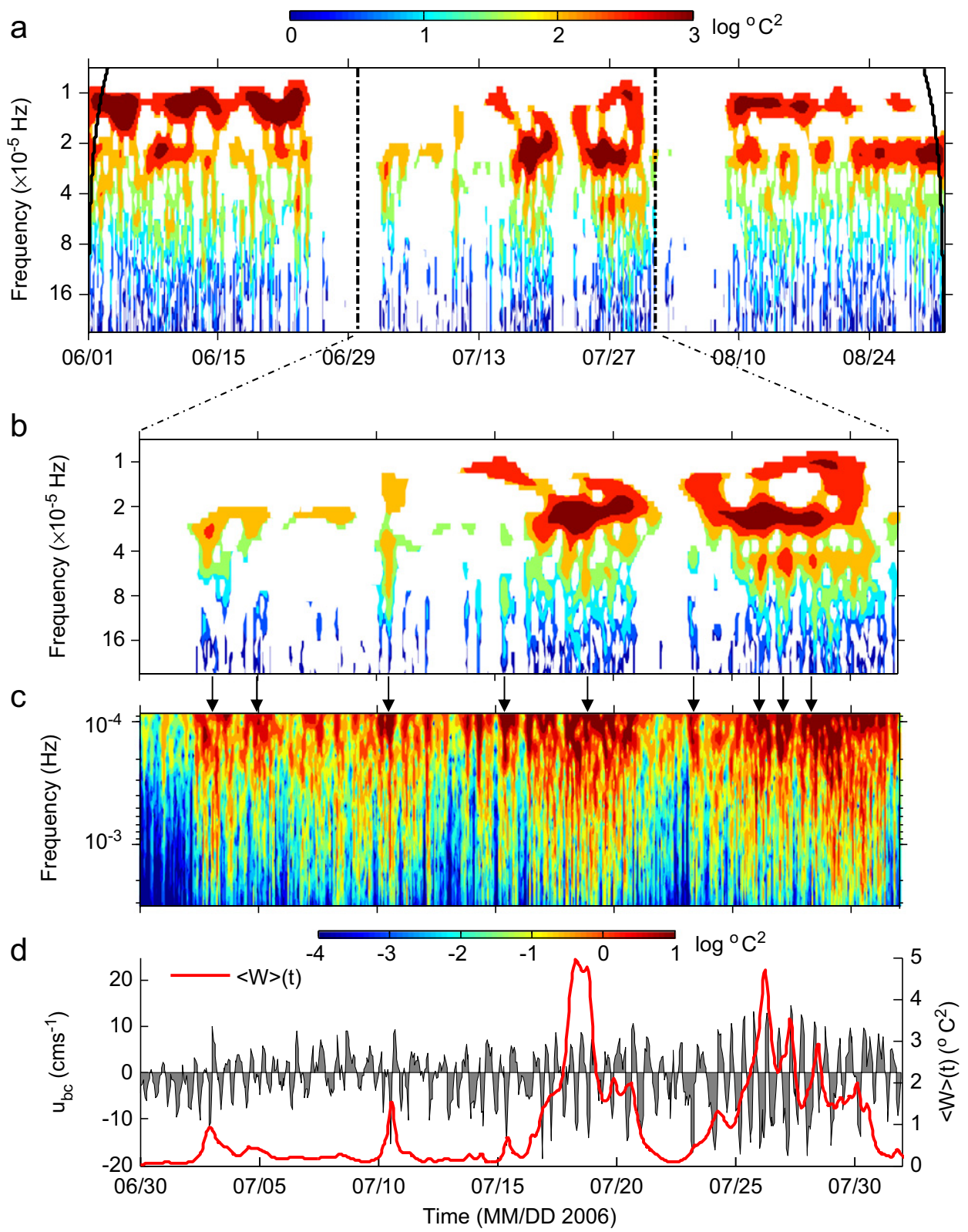

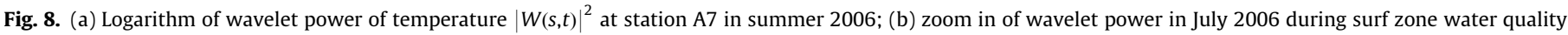

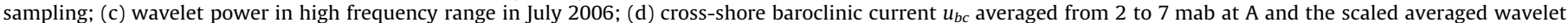
power at A7 in July 2006. See the caption of Fig. 7 for more details.

resulting in a low temporal resolution of wavelet power (Torrence and Compo, 1998). The comparison shows that the near bottom cross-shore baroclinic current at A as positively, significantly correlated with the wavelet power of temperature at A5, A7, D0, HP (Table 4). The significant correlation between the proxy and wavelet power at various stations supports the connection between strong bottom cross-shore baroclinic currents and high intensity internal wave activity.

For comparison with surf zone water quality, $u_{b c}$ was temporally averaged over $4 \mathrm{~h}$ and lagged by $6 \mathrm{~h}$ before each water sampling time. By averaging over $4 \mathrm{~h}$, the proxy has its largest value during periods of persistent, strong onshore flow. The $4 \mathrm{~h}$ average was best correlated to the temperature at HP (during summers of 2005 and 2006) at a lag of $6 \mathrm{~h}$. Thus the $6 \mathrm{~h}$ lag corresponds to the average time of internal wave propagation from $A$ to the coast. For example, the temperature measured at $\mathrm{HP}$ at $1700 \mathrm{~h}$ was best correlated with $u_{b c}$ averaged between 0700 and $1100 \mathrm{~h}$ on the same day. Averaging periods other than $4 \mathrm{~h}$ were also tested and found not to provide better correlations with cooling at HP. An alternative proxy consisting of the product of $u_{b c}$ and the wavelet power of temperature was also considered. The inclusion of the signatures of the temperature fluctuations in the proxy resulted in generally the same association between the proxy and all water quality variables as using the proposed proxy that uses just $u_{b c}$. For simplicity, the internal wave proxy was defined based on $u_{b c}$ only.

\subsection{Correlation of internal waves and twice daily water quality}

Table 5 shows the correlation between the internal wave proxy (i.e., the bottom cross-shore baroclinic current, $4 \mathrm{~h}$ averaging and $6 \mathrm{~h}$ lag) and the twice-daily surf zone water quality parameters at HSB in August $2005(n=56)$ and July $2006(n=54)$. In August 2005, the proxy was positively correlated with phosphate $(\rho=0.42, p<0.05)$ and silicate $(\rho=0.34, p<0.05)$, but was not significantly correlated 
a

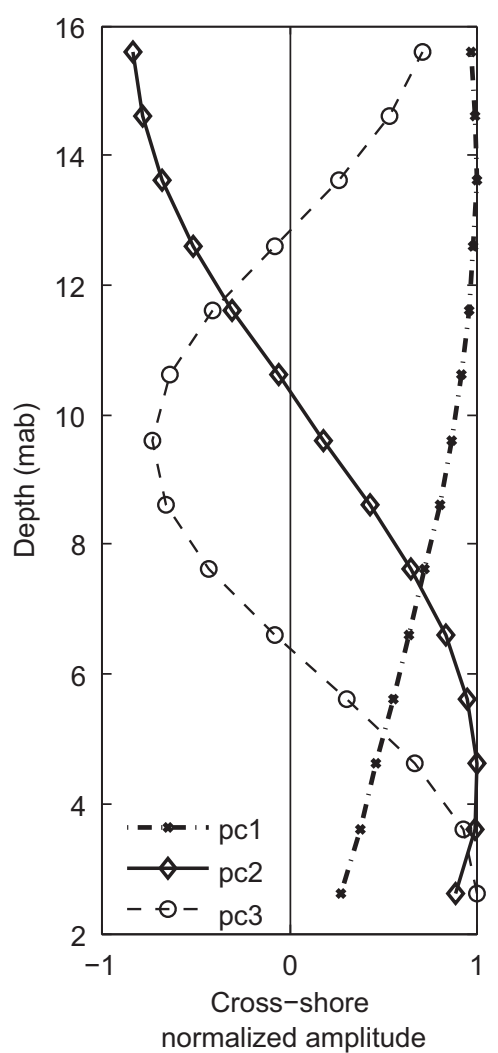

b

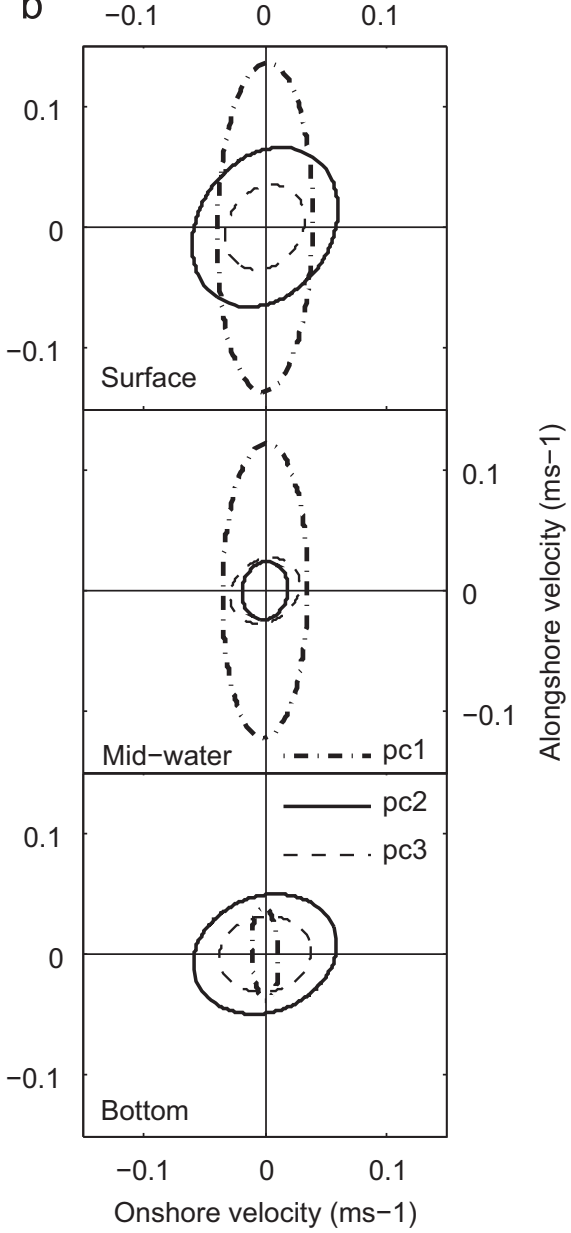

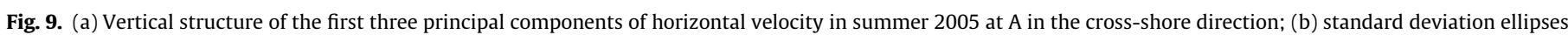

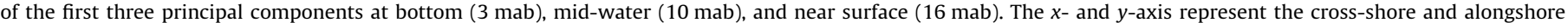
direction, respectively.

a

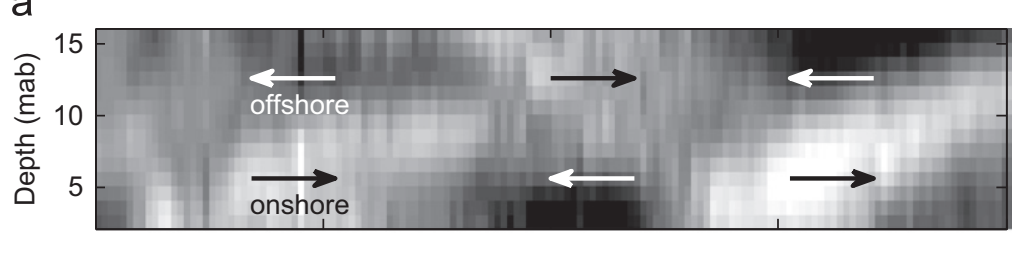

b

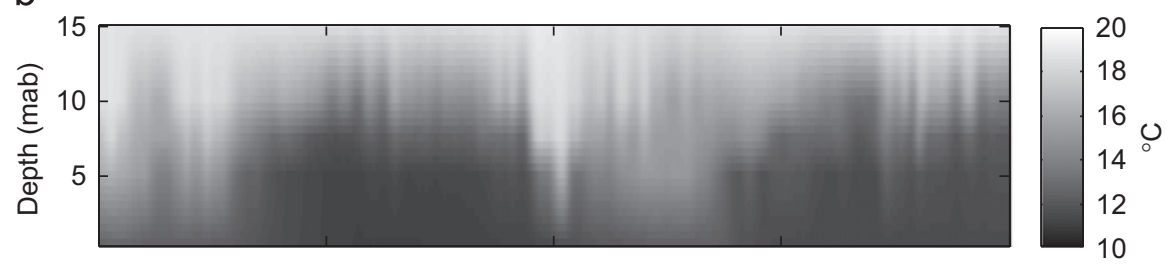

C

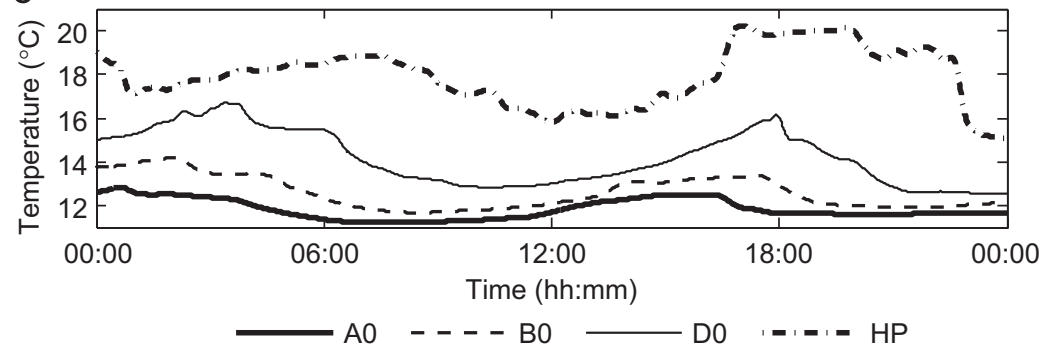

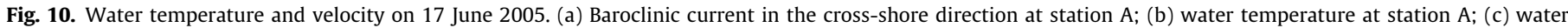
temperature at A0, BO, D0, and Huntington Pier (HP). All temperature data were low-passed at 15 min. 


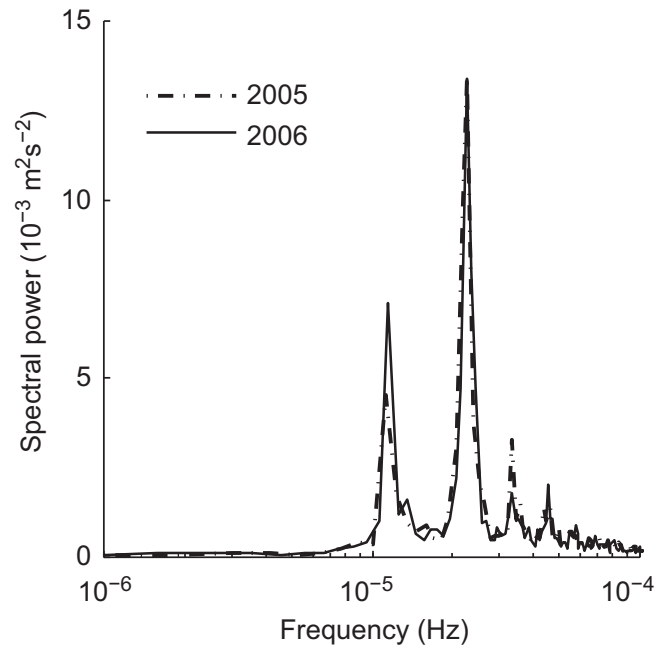

Fig. 11. Variance-preserving power spectra of the internal wave proxy in summer 2005 and 2006.

Table 4

Spearman's rank correlation between daily maximum bottom cross-shore baroclinic current magnitude at A and daily maximum wavelet power at selected stations in summer 2005 and 2006. N/A=temperature was not measured at B0 and D0 in summer 2006. Correlations with asterisks were significant at $p<0.05$.

\begin{tabular}{lll}
\hline Station & 2005 & 2006 \\
\hline A0 & 0.13 & $0.57^{*}$ \\
A5 & $0.52^{*}$ & $0.65^{*}$ \\
A7 & $0.52^{*}$ & $0.63^{*}$ \\
B0 & 0.19 & $\mathrm{~N} / \mathrm{A}$ \\
D0 & $0.41^{*}$ & $\mathrm{~N} / \mathrm{A}$ \\
HP & $0.45^{*}$ & 0.04 \\
\hline
\end{tabular}

Table 5

Spearman's rank correlation between the internal wave proxy and surf zone water quality in August 2005 and July 2006. Correlations with asterisks are statistically significant at $p=0.05$.

\begin{tabular}{lcc}
\hline Parameter & August 2005 & July 2006 \\
\hline Total coliform & 0.17 & $0.47^{*}$ \\
E. coli & 0.16 & $0.49^{*}$ \\
Enterococci & 0.20 & $0.33^{*}$ \\
Chl a & -0.04 & -0.03 \\
Phosphate & $0.42^{*}$ & $0.32^{*}$ \\
Silicate & $0.34^{*}$ & 0.03 \\
DIN & 0.18 & 0.22 \\
\hline
\end{tabular}

to FIB concentrations. In July 2006, the proxy was positively correlated with phosphate $(\rho=0.32, p<0.05)$ and all three FIB $(p<0.05)$. The correlations with total coliform $(\rho=0.47)$ and $E$. coli ( $\rho=0.49$ ) were higher than the correlation with enterococci $(\rho=0.33)$. The proxy was not correlated with chl a in either year.

The non-parametric Kruskal-Wallis test was used to examine whether the proxy was associated with the occurrence of human fecal (HF) markers at HSB. The bottom onshore baroclinic current was not significantly higher when HF markers were found in the surf zone.

\section{Discussion}

Consistent with previous studies at the field site (Boehm et al., 2002b; Noble et al., 2009; Nam and Send, 2011), we observed predominantly semi-diurnal mode- 1 progressive internal waves during the study periods of summer 2005 and 2006 in 10-20 m waters off Huntington Beach and an association between nearshore cooling and onshore flow of subthermocline water. Cold subthermocline water was periodically carried towards/away from the shore along the bottom by the corresponding shoreward/seaward near bottom baroclinic flow. These repeated motions could cause significant cross-shore displacement of the $13{ }^{\circ} \mathrm{C}$ isotherm, for example, by as much as $2 \mathrm{~km}$ in $6 \mathrm{~h}$ from $\mathrm{A}$ to D on 17 June 2005 (Fig. 10c). Using the array of temperature data and velocity at A in summer 2005 , we conducted a heat budget analysis of bottom temperature similar to the one reported by Boehm et al. (2002b) (results not shown) and found that the nearshore cooling was well accounted for by cross-shore heat advection near the bottom, consistent with the previous results. The heat exchange at the air-sea interface can influence the heat budget of coastal waters (Price et al., 1986) and was not explicitly considered in this study. However, the heat balance we conducted indicated that heat transport was strongly dominated by crossshore advection, thus air-sea interface heat exchange was likely not significant. This study did not attempt to delineate the origin of the observed internal waves. It has been proposed that they are generated offshore of the shelf (Noble et al., 2009) and driven by surface tides (Nam and Send, 2011).

Internal waves other than semi-diurnal internal tides were also evident in the records. The wavelet analysis indicated that most of the variance was typically in the semi-diurnal band. However, the diurnal and high frequency bands also contained substantial fractions of the total variance. Temperature and current fluctuations at the diurnal frequency have been reported at the site previously (Boehm et al., 2002b; Nam and Send, 2011). Although subinertial waves cannot propagate freely in the region near Huntington Beach, negative vorticity generated by the horizontal shear of subtidal currents can decrease the effective inertial frequency and allow propagation of subinertial waves (Lerczak et al., 2001). Positive correlations between temperature in the diurnal band with onshore wind suggests that the diurnal temperature fluctuations in this region could be caused by diurnal sea breeze (Noble et al., 2003; Pidgeon and Winant, 2005; Woodson et al., 2007; Cudaback and McPheeShaw, 2009).

High frequency internal waves were observed at this site, consistent with the reports by Nam and Send (2011). The percentage of total energy in the high frequency band was approximately $7-10 \%$ at all stations in the cross-shore array. This could suggest that there is not significant transfer of energy from lower frequency internal waves into high-frequency internal waves between A and surf zone (Rudnick et al., 2003), although some of the energy cascade could occur at deeper water on the continental shelf offshore of A. The positive correlations of wavelet power in high frequency and semi-diurnal bands at all stations suggest that internal waves in these two bands could be driven by the same forcing mechanisms.

This study examined temporal variation in the strength of internal waves using wavelet analysis, an analysis that has not been done at the site before. In general, freely propagating internal waves $\left(1.28 \times 10^{-5} \mathrm{~Hz}<f<0.03 \mathrm{~Hz}\right)$ were present when the water column was strongly stratified and when subthermocline currents were strong in the cross-shore direction. The present study examined several variables that may influence the forcing of internal waves (wind, tides) or their propagation (stratification). The observed association between temperature and its wavelet power, and stratification and wind is consistent with Cudaback and McPhee-Shaw (2009), who observed a dependence of internal wave amplitudes on thermal stratification and diurnal sea breeze at another site in California. 
While some studies have reported a lunar cycle of internal wave activity along the western U.S.A. (Pineda, 1995), this study found no significant correlation between the internal wave proxy, in terms of its daily maximum value, and tidal range in both summer 2005 and 2006 ( $\rho=-0.08, p=0.46$ in 2005; $\rho=-0.11$, $p=0.48$ in 2006). The limited length of data in this study (2 summers vs. 18-68 years of data in Pineda, 1995) may prevent us from observing any lunar pattern that might exist, which, in particular, could be masked by the non-uniform stratification during the two summers (Figs. 4a, 5a).

Subthermocline water (water cooler than $15^{\circ} \mathrm{C}$ ) contained elevated levels of phosphate, silicate, and nitrate relative to the surf zone. Hayward and Venrick (1998) observed this stable relationship between temperature and nutrients in a larger set of offshore water quality data from CalCOFI. Due to the high variability of FIB in sewage discharge (Table 2), these same waters may contain FIB from disinfected wastewater at times in elevated concentrations, and at other times in quite low concentrations. Together, subthermocline waters represent potentially persistent sources of nutrients to the nearshore and periodic sources of FIB.

The temporally averaged and lagged bottom cross-shore baroclinic current at A was used as a proxy for the presence of strong internal waves at the field site. The significant correlation between the proxy and shoreline temperature at the appropriate time lag suggests that the proxy is indicative of the cross-shore transport of cold subthermocline water. This directional proxy is preferable over a proxy based on nearshore temperature because temperature changes can be the result of various physical mechanisms, whereas the directional proxy measures only the cross-shore transport of subthermocline water by baroclinic motions. At HSB, located shoreward of station A, the proxy was positively correlated with phosphate (2005 and 2006) and silicate (2005); no other correlations with nutrients were observed. Although other factors such as alongshore wind stress and isotherm tilting can control cross-shore transport (Noble et al., 2009), these results are consistent with the hypothesis that internal waves could transport nutrient rich waters to the shoreline.

Offshore nutrient data indicate that the N:P was below the Redfield ratio of 16:1 (Redfield, 1934) (Fig. 2), consistent with previous findings that the coastal waters in this region are nitrogen-limited (Eppley, 1968). The rapid consumption of dissolved inorganic nitrogen by phytoplankton in the nearshore waters might explain the lack of correlation of the internal wave proxy with dissolved inorganic nitrogen, but a positive relationship in both years with phosphorous. Lucas et al. (2011a) demonstrated that the internal tide was an important delivery mechanism of nitrate to the inner shelf in Southern California Bight. They found, however, that the delivery of nitrate by the internal tide was modulated by the depth of the nutricline, a parameter not measured in the present study.

The internal wave proxy was positively correlated with total coliform, E. coli, and enterococci in 2006, however, there was no significant correlation between the internal wave proxy and FIB in 2005. Assuming that the positive correlations in 2006 are indicative of cross-shore transport of FIB, these results provide one possible explanation for previous reports of a negative relationship between FIB and nearshore water temperature (Boehm et al., 2004a). Shoreline FIB concentrations were lower in 2005 than in 2006 (Santoro and Boehm, 2007); it is possible that low levels precluded identification of relationships between variables. The wavelet analysis indicated that the internal wave intensity was lower in August 2005 than in July 2006, and so we speculate that low FIB levels could potentially be due to the lack of internal waves. There were no significant differences between water quality of discharged effluent in 2005 and 2006 (data not shown), so assuming the source of contamination was the effluent, it is unlikely that the difference in correlations between years was caused by the change in source concentration.

In general, these results suggest a complex interplay of physical and biological mechanisms influencing water quality in the very nearshore. One potential explanation is that subthermocline waters are enriched with FIB during this period, acting as a FIB source, and delivery of nutrients or particles on low tide from land acts to increase the persistence of FIB transported from offshore. The estimated travel time of subthermocline water from shelf break to $20 \mathrm{~m}$ depth (3-13 h) was an order of magnitude smaller than the reported range of time for $90 \%$ decay $\left(T_{90}\right)$ of various FIB in dark seawater (100-500 h, Table 6), suggesting that, if present in subthermocline waters, FIB would decay minimally by the time they reach nearshore waters. There was no significant difference in the internal wave proxy with the presence and absence of HF markers at HSB. While we had no data on the occurrence of HF markers in offshore waters, they are presumably present in the effluent of the OCSD outfall (Bernhard and Field, 2000), and so the transport of FIB from offshore may not entirely explain the observed correlations.

A second explanation for the observed correlations is that cold, nutrient-rich subthermocline waters transported to the surf zone by internal waves may increase persistence of FIB from landbased sources, which have been suggested to be important in this region (Grant et al., 2001; Kim et al., 2004). Increased bacterial persistence in dark, cold and nutrient-rich waters have been documented (Auer and Niehaus, 1993; Johnson et al., 1997; Noble et al., 2004). Hence, transport of off-shore water to the nearshore zone via internal waves may facilitate bacterial persistence along the shore line. The difference in correlations in FIB between years could be a result of the variability of the strength of land-based sources.

This study has several limitations. First, it relies on correlation analysis, and correlation does not ensure causation. The study found correlations between an internal wave proxy and surf zone water quality parameters. Synoptic studies that document the internal wave driven transport of subthermocline water, along with coupled water quality measurements of the water as it advances across the shelf and into the surf zone can confirm the conclusions of this study (Leichter et al., 1998; Omand et al., 2011). Second, our statistical analyses were hypothesis-driven, intending to determine if the data support a connection between internal waves on the continental shelf and surf zone water quality. We did not investigate how alternative processes might influence water quality along the shore. Indeed, previous work has identified possible influence by groundwater discharge (Boehm et al., 2004b), watershed outlets to the south of the site (Grant et al., 2001; Santoro and Boehm, 2007), and upwelling (Boehm et al., 2004a). Finally, a major difficulty in conducting a study of coupled physical, chemical, and microbiological processes is that while physical parameters can usually be measured at a high frequency with sensors, chemical and microbiological parameters typically cannot. In the present study, continuous in situ measurements of FIB, nutrients, and chlorophyll

Table 6

Inactivation rates of fecal indicator bacteria in dark seawater from the literature.

\begin{tabular}{llll}
\hline FIB & $k\left(\mathrm{~s}^{-1}\right)$ & $\mathrm{T}_{90}(\mathrm{~h})$ & Reference \\
\hline Total coliform & $5.3 \times 10^{-6}$ & 121 & Noble et al. (2004) \\
E. coli & $5.9 \times 10^{-6}$ & 108 & Noble et al. (2004) \\
Fecal coliform & $8.4 \times 10^{-6}$ & 76 & Auer and Niehaus (1993) \\
Fecal coliform & $5.6 \times 10^{-6}$ & 114 & Sinton et al. (1994) \\
Enterococci & $4.4 \times 10^{-6}$ & 145 & Noble et al. (2004) \\
Enterococci & $2.2 \times 10^{-6}$ & 291 & Sinton et al. (1994) \\
Enterococci & $1.4 \times 10^{-6}$ & 457 & Sinton et al. (1999) \\
\hline
\end{tabular}


a at a frequency higher than twice per day would be desirable. However, the lack of reliable in situ measurement equipment for certain parameters (e.g., FIB), the difficulty of equipment deployment in the turbulent surf zone, and practical constraints in labor resources, made more intensive sampling impossible. When technological advances enable reliable chemical and microbiological sensors, this study may be repeated to further verify the conclusions.

\section{Conclusion}

This study proposed a proxy based on the bottom cross-shore baroclinic current at $20 \mathrm{~m}$ depth to measure the time-varying shoreward transport potential by internal waves. The positive correlations of the internal wave proxy with FIB concentrations and nutrients in the surf zone are consistent with previous findings that the persistence of FIB is enhanced in cold and dark water and the hypothesis that internal waves can drive crossshore transport nutrient-rich and potentially FIB-rich cold subthermocline water to the nearshore. The temporal variability in this correlation illustrates that multiple physical and biological mechanisms contribute to water quality at this field site, which still have not yet been fully elucidated.

\section{Acknowledgments}

This study was funded by the NOAA Oceans and Human Health Initiative (to A.B.B.). A.E.S. was supported by an NSF Graduate Research Fellowship. S.H.W. was supported by a Croucher Foundation Scholarship from Hong Kong. We acknowledge Orange County Sanitation District for the use of M/V Nerissa and supplying the outfall monitoring data. We acknowledge Kristen Davis, Fred O'Brien, George Robertson, and Johanna Rosman for their assistance in equipment deployment and recovery. We acknowledge the help by Pat Leahy of Kerckhoff Marine Laboratory. We also thank the lifeguards of Newport and Huntington State Beach for access to sampling locations. Finally, we appreciate the reviews and comments from Erika McPhee-Shaw and an anonymous reviewer that improved the final edition of this paper.

\section{References}

Ahn, J.H., Grant, S.B., Surbeck, C.Q., DiGiacomo, P.M., Nezlin, N.P., Jiang, S., 2005 Coastal water quality impact of stormwater runoff from an urban watershed in southern California. Environmental Science \& Technology 39 (16), 5940-5953.

Auer, M.T., Niehaus, S.L., 1993. Modeling fecal coliform bacteria-i. Field and laboratory determination of loss kinetics. Water Research 27 (4), 693-701.

Bernhard, A.E., Field, K.G., 2000. A PCR assay to discriminate human and ruminant feces on the basis of host differences in Bacteroides-Prevotella genes encoding 16s rRNA. Applied and Environmental Microbiology 66 (10), 4571

Boehm, A.B., Grant, S.B., Kim, J.H., Mowbray, S.L., McGee, C.D., Clark, C.D., Foley, D.M., Wellman, D.E., 2002a. Decadal and shorter period variability of surf zone water quality at Huntington Beach, California. Environmental Science \& Technology 36 (18), 3885-3892.

Boehm, A.B., Lluch-Cota, D.B., Davis, K.A., Winant, C.D., Monismith, S.G., 2004a. Covariation of coastal water temperature and microbial pollution at interannual to tidal periods. Geophysical Research Letters 31, L06309.

Boehm, A.B., Sanders, B.F., Winant, C.D., 2002b. Cross-shelf transport at Huntington Beach. Implications for the fate of sewage discharged through an offshore ocean outfall. Environmental Science and Technology 36 (9), 1899-1906.

Boehm, A.B., Shellenbarger, G.G., Paytan, A., 2004b. Groundwater discharge: potential association with fecal indicator bacteria in the surf zone. Environmental Science and Technology 38 (13), 3558-3566.

Chelton, D.B., 1984. Commentary: short-term climatic variability in the northeas Pacific Ocean. In: Pearcy, W.G. (Ed.), The Influence of Ocean Conditions on the Production of Salmonids in the North Pacific. , Oregon State University Press, pp. 87-99.

Cudaback, C.N., McPhee-Shaw, E., 2009. Diurnal-period internal waves near Poin Conception, California. Estuarine, Coastal and Shelf Science 83 (3), 349-359. de Sieyes, N., Yamahara, K., Paytan, A., Boehm, A., 2011. Submarine groundwater discharge to a high-energy surf zone at Stinson Beach, California, estimated using radium isotope. Estuaries and Coasts 34 (2), 256-268.

Edwards, C.R., Seim, H.E., 2008. Complex EOF analysis as a method to separate barotropic and baroclinic velocity structure in shallow water. Journal of Atmospheric and Oceanic Technology 25 (5), 808-821.

Eppley, R., 1968. An incubation method for estimating the carbon content of phytoplankton in natural samples. Limnology and Oceanography 13 (4), 574-582.

Farge, M., 1992. Wavelet transforms and their applications to turbulence. Annual Review of Fluid Mechanics 24 (1), 395-458.

Fofonoff, N., Millard, R., 1983. Algorithms for computation of fundamental properties of seawater. UNESCO Technical Papers in Marine Science 44.

Gannon, J., Busse, M., 1989. E. coli and enterococci levels in urban stormwater, river water and chlorinated treatment plant effluent. Water Research 23 (9), 1167-1176.

Garrett, C., Munk, W., 1979. Internal waves in the ocean. Annual Review of Fluid Mechanics 11 (1), 339-369.

Gill, A.E., 1982. Atmosphere-Ocean Dynamics. Academic Press, New York.

Grant, S.B., Sanders, B.F., Boehm, A.B., Redman, J.A., Kim, J.H., Mrše, R.D., Chu, A.K., Gouldin, M., McGee, C.D., Gardiner, N.A., et al., 2001. Generation of enterococci bacteria in a coastal saltwater marsh and its impact on surf zone water quality. Environmental Science and Technology 35 (12), 2407-2416.

Hamilton, P., Noble, M.A., Largier, J., Rosenfeld, L.K., Robertson, G., 2006. Crossshelf subtidal variability in San Pedro Bay during summer, 2001. Continental Shelf Research 26 (6), 681-702.

Hayward, T.L., Venrick, E.L., 1998. Nearsurface pattern in the California Current: coupling between physical and biological structure. Deep-Sea Research Part II 45 (8-9), 1617-1638.

Helfrich, K.R., Melville, W.K., 2006. Long nonlinear internal waves. Annual Review of Fluid Mechanics 38, 395-425.

Johnson, D.C., Enriquez, C.E., Pepper, I.L., Davis, T.L., Gerba, C.P., Rose, J.B., 1997. Survival of giardia, cryptosporidium, poliovirus and salmonella in marine waters. Water Science and Technology 35 (11-12), 261-268.

Jones, B.H., Noble, M.A., Dickey, T.D., 2002. Hydrographic and particle distributions over the Palos Verdes Continental Shelf: spatial, seasonal and daily variability. Continental Shelf Research 22 (6-7), 945-965.

Kim, J.H., Grant, S.B., McGee, C.D., Sanders, B.F., Largier, J.L., 2004. Locating sources of surf zone pollution: a mass budget analysis of fecal indicator bacteria at Huntington Beach, California. Environmental Science \& Technology 38 (9), 2626-2636.

Lee, Y.W., Kim, G., 2007. Linking groundwater-borne nutrients and dinoflagellate red-tide outbreaks in the southern sea of Korea using a Ra tracer. Estuarine, Coastal and Shelf Science 71 (1-2), 309-317.

Leichter, J.J., Shellenbarger, G., Genovese, S.J., Wing, S.R., 1998. Breaking internal waves on a Florida (USA) coral reef: a plankton pump at work? Marine Ecology Progress Series 166, 83-97.

Leichter, J.J., Wing, S.R., Miller, S.L., Denny, M.W., 1996. Pulsed delivery of subthermocline water to Conch Reef (Florida Keys) by internal tidal bores. Limnology and Oceanography 41 (7), 1490-1501.

Lerczak, J.A., Hendershott, M.C., Winant, C.D., 2001. Observations and modeling of coastal internal waves driven by a diurnal sea breeze. Journal of Geophysical Research 106 (C9), 19715-19729.

Lucas, A.J., Dupont, C.L., Tai, V., Largier, J.L., Palenik, B., Franks, P.J.S., 2011a. The green ribbon: multiscale physical control of phytoplankton productivity and community structure over a narrow continental shelf. Limnology and Oceanography $56(2), 611-626$.

Lucas, A.J., Franks, P.J.S., Dupont, C.L., 2011b. Horizontal internal-tide fluxes support elevated phytoplankton productivity over the inner continental shelf. Limnology and Oceanography: Fluids and Environments 1, 56.

Munk, W., Wunsch, C., 1998. Abyssal recipes II: energetics of tidal and wind mixing. Deep-Sea Research Part I 45 (12), 1977-2010.

Nam, S.H., Send, U., 2011. Direct evidence of deep water intrusions onto the continental shelf via surging internal tides. Journal of Geophysical Research 116 (C5), C05004.

Noble, M., Jones, B., Hamilton, P., Xu, J., Robertson, G., Rosenfeld, L., Largier, J., 2009. Cross-shelf transport into nearshore waters due to shoaling internal tides in San Pedro Bay, CA. Continental Shelf Research 29 (15), 1768-1785.

Noble, M., Xu, J., Rosenfeld, L., Largier, J., Hamilton, P., Jones, B., Robertson, G., 2003. Huntington Beach shoreline contamination investigation, phase III. US Geological Survey Open-File Report 2003-62.

Noble, R.T., Lee, I.M., Schiff, K.C., 2004. Inactivation of indicator micro-organisms from various sources of faecal contamination in seawater and freshwater. Journal of Applied Microbiology 96 (3), 464-472.

Omand, M.M., Leichter, J.J., Franks, P.J.S., Guza, R.T., Lucas, A.J., Feddersen, F., 2011. Physical and biological processes underlying the sudden surface appearance of a red tide in the nearshore. Limnology and Oceanography 56 (3), 787-801.

Orange County Sanitation District, 2006. Ocean Monitoring Program 2005-2006 Annual Report. Fountain Valley, California.

Pidgeon, E.J., Winant, C.D., 2005. Diurnal variability in currents and temperature on the continental shelf between Central and Southern California. Journal of Geophysical Research 110 (C3), C03024.

Pineda, J., 1991. Predictable upwelling and the shoreward transport of planktonic larvae by internal tidal bores. Science 253 (5019), 548-549. 
Pineda, J., 1994. Internal tidal bores in the nearshore: warm-water fronts, seaward gravity currents and the onshore transport of neustonic larvae. Journal of Marine Research 52 (3), 427-458.

Pineda, J., 1995. An internal tidal bore regime at nearshore stations along western USA: predictable upwelling within the lunar cycle. Continental Shelf Research 15 (8), 1023-1041.

Price, J.F., Weller, R.A., Pinkel, R., 1986. Diurnal cycling: observations and models of the upper ocean response to diurnal heating, cooling, and wind mixing. Journal of Geophysical Research 91 (C7), 8411-8427.

Pringle, J.M., Riser, K., 2003. Remotely forced nearshore upwelling in Southern California. Journal of Geophysical Research 108, 3131.

Redfield, A.C., 1934. On the Proportions of Organic Derivatives in Sea Water and Their Relation to the Composition of Plankton. University Press of Liverpool.

Reifel, K.M., Johnson, S.C., DiGiacomo, P.M., Mengel, M.J., Nezlin, N.P., Warrick, J.A., Jones, B.H., 2009. Impacts of stormwater runoff in the Southern California Bight: relationships among plume constituents. Continental Shelf Research 29 (15), 1821-1835.

Rosenfeld, L.K., McGee, C.D., Robertson, G.L., Noble, M.A., Jones, B.H., 2006. Temporal and spatial variability of fecal indicator bacteria in the surf zone off Huntington Beach, CA. Marine Environmental Research 61 (5), 471-493.

Rudnick, D.L., Boyd, T.J., Brainard, R.E., Carter, G.S., Egbert, G.D., Gregg, M.C., Holloway, P.E., Klymak, J.M., Kunze, E., Lee, C.M., et al., 2003. From tides to mixing along the Hawaiian Ridge. Science 301 (5631), 355.

Saggio, A., Imberger, J., 1998. Internal wave weather in a stratified lake. Limnology and Oceanography 43 (8), 1780-1795.

Santoro, A., Boehm, A., 2007. Frequent occurrence of the human-specific Bacteroides fecal marker at an open coast marine beach: relationship to waves, tides and traditional indicators. Environmental Microbiology 9 (8), 2038-2049.
Santoro, A.E., Nidzieko, N.J., Van Dijken, G.L., Arrigo, K.R., Boehm, A.B., 2010 Contrasting spring and summer phytoplankton dynamics in the nearshore Southern California Bight. Limnology and Oceanography 55 (1), 264-278.

Shanks, A.L., 1983. Surface slicks associated with tidally forced internal waves may transport pelagic larvae of benthic invertebrates and fishes shoreward. Marine Ecology Progress Series 13 (2), 311-315.

Sinton, L., Davies-Colley, R., Bell, R., 1994. Inactivation of enterococci and fecal coliforms from sewage and meatworks effluents in seawater chambers. Applied and Environmental Microbiology 60 (6), 2040.

Sinton, L., Finlay, R., Lynch, P., 1999. Sunlight inactivation of fecal bacteriophages and bacteria in sewage-polluted seawater. Applied and Environmental Microbiology 65 (8), 3605.

Stacey, M.T., Burau, J.R., Monismith, S.G., 2001. Creation of residual flows in a partially stratified estuary. Journal of Geophysical Research 106 (17), 17013-17037.

Torrence, C., Compo, G., 1998. A practical guide to wavelet analysis. Bulletin of the American Meteorological Society 79 (1), 61-78.

Turner, J.S., 1973. Buoyancy Effects in Fluids, 1st ed. Cambridge University Press.

U.S. Environmental Protection Agency, 1986. Ambient water quality criteria for bacteria. Washington, DC.

Valiela, I., Costa, J., Foreman, K., Teal, J.M., Howes, B., Aubrey, D., 1990. Transport of groundwater-borne nutrients from watersheds and their effects on coastal waters. Biogeochemistry 10 (3), 177-197.

Venayagamoorthy, S.K., Fringer, O.B., 2007. On the formation and propagation of nonlinear internal boluses across a shelf break. Journal of Fluid Mechanics 577, 137-159.

Woodson, C.B., Eerkes-Medrano, D.I., Flores-Morales, A., Foley, M.M., Henkel, S.K., Hessing-Lewis, M., Jacinto, D., Needles, L., Nishizaki, M.T., O'Leary, J., et al. 2007. Local diurnal upwelling driven by sea breezes in northern Monterey Bay. Continental Shelf Research 27 (18), 2289-2302. 